اثر منطقه توليد و اندازه بذر بر شاخصهاى جوانهزنى و اجزاى رشد هتروتروفيك تياهجه (Arachis hypogaea) بادامزمينى

\author{
سيد على نور حسينى" "، محمدنقى صفرزاده ‘، سيد مصطفى صادقى "

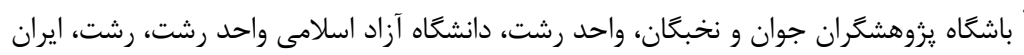

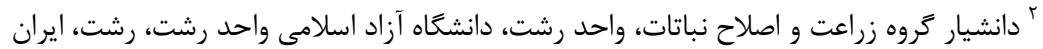

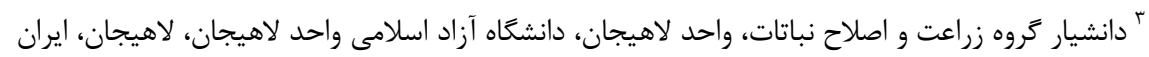

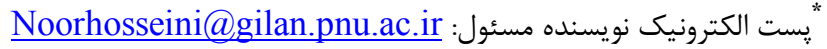

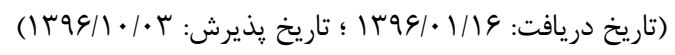

جكيده

بلهمنظور بررسى اثر منطقه توليد و اندازه بذر بر شاخصهاى جوانهزنى و رشد هتروتروفيك تياهجه

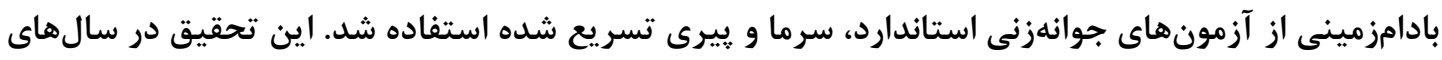

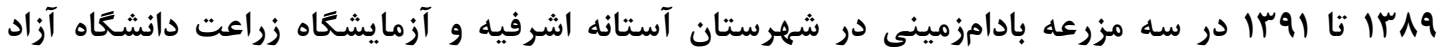

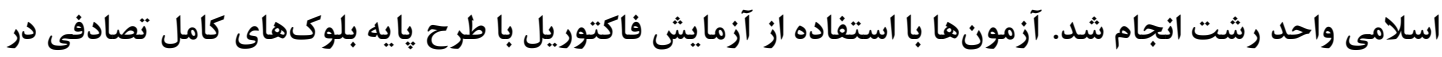

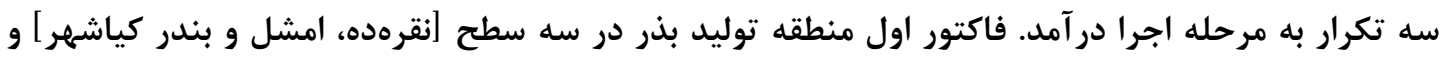

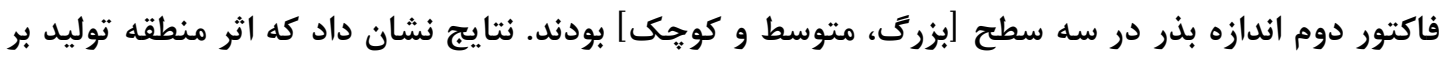

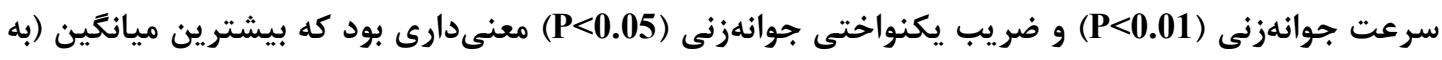

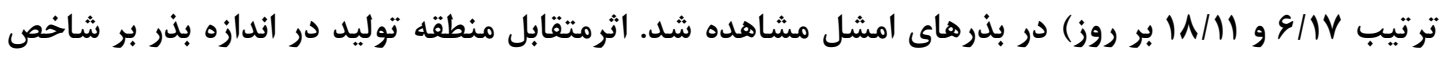

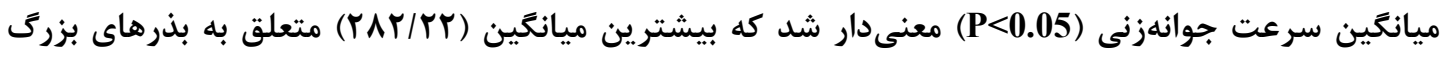

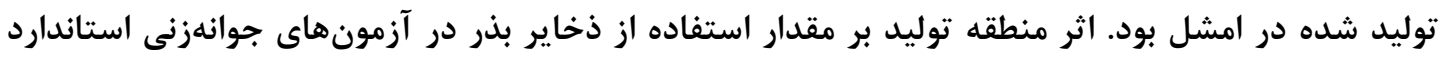

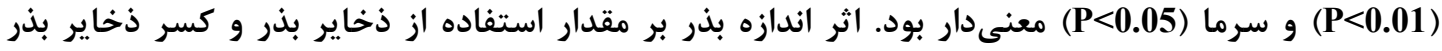

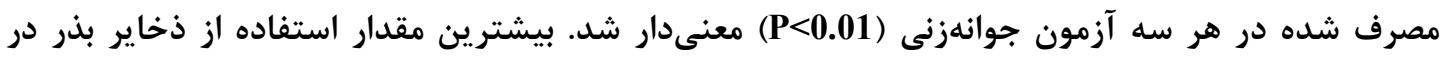

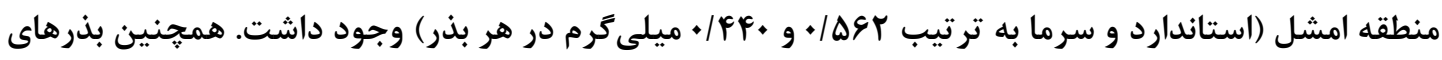

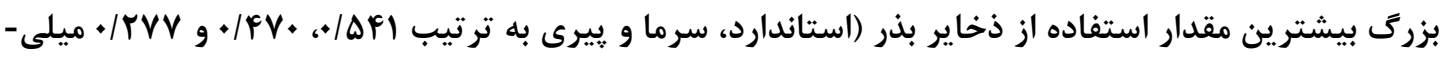

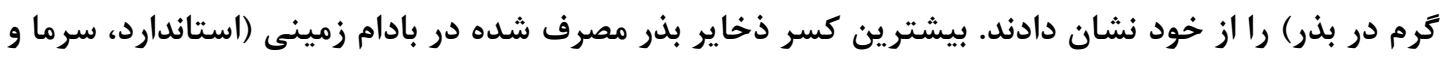

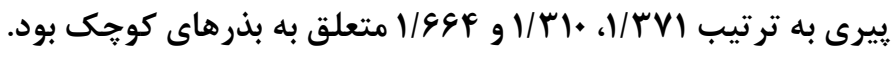

وازههاى كليدى: بادام زمينى، بنيه بذر، يِيرى تسريع شده، ذخاير بذر، وزن بذر

جنبه هاى نو آورى:

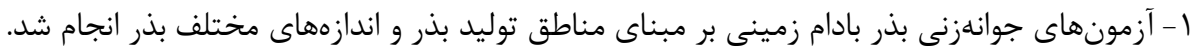

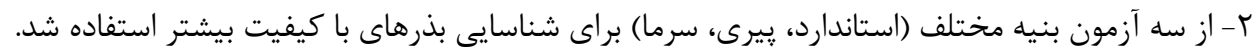

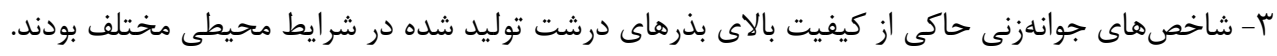

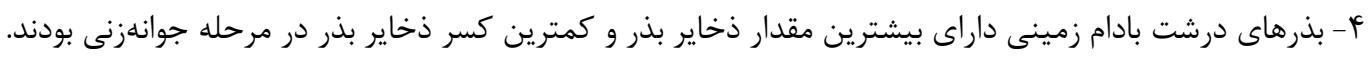

DOI: $10.29252 /$ yujs.4.2.57

CrossMark 
تخمين مناسبى را از شاخصهاى جوانهزنى را بهدست

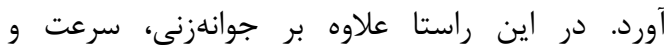
يكنواختى جوانهزنى نيز از يارامترهاى هـهم مؤثر در كيفيت بذر مىباشند كه قابل اندازهيرى است (كايلند و

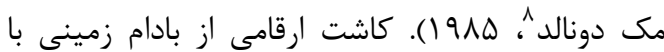
اندازهاى بزرگ، متوسط و كوجى نشان داد كه درصد سبز شدن به طور قابل توجهى بين آنها متفاوت بود

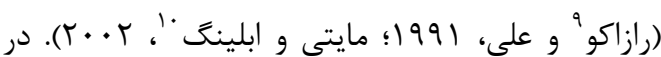

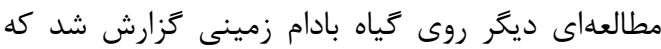
سرعت سبز شدن و سبز شدن جزئى بذرهاى كوجى درى

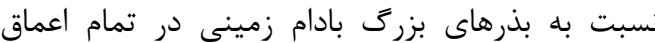

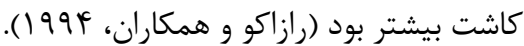
رشد هتروتروفيك كياهجهها را مىتوان بر اساس دوان جزء وزن ذخاير بذر انتقاليافته يا يويا شده و كارايى تبديل ذخاير بذر انتقال يافته به بافت كياهجه تقسيم كرد (سلطانى و همكاران، 9. •. بـ؛ سلطانى و همكاران،

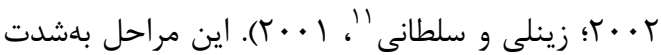

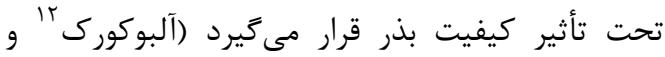

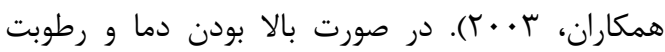
نسبى محيط، بذرها سريعتر زوال يافته و ضمن كاهش

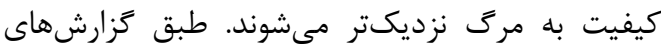

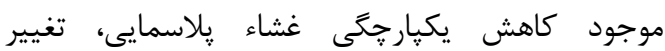

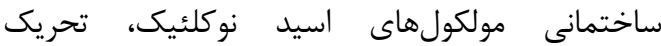
يراكسيداسيون ليبيدها و كاهش فعاليت آنزيمهاى هيدروليتيك از مههمترين تغييراتى است كه در زمان زوال در بذر ايجاد مىشوند كه اين تغييرات مىتواند به

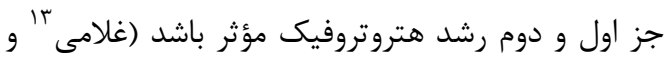

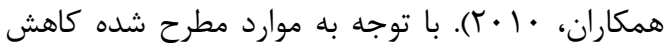
مقدار استفاده از ذخاير بذر و كاهش نسبت ذخاير انتقال يافته بذر به كياهجه مىتواند بهدليل كاهش هورمون

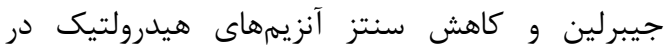

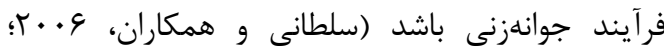

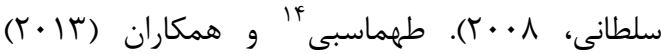

\footnotetext{
${ }^{8}$ Copeland and McDonald

${ }^{9}$ Razzaque

${ }^{10}$ Maiti and Ebeling

${ }^{11}$ Zeinali and Soltani

${ }^{12}$ Albuquerque

${ }^{13}$ Gholami

14 Tahmasebi
}

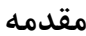

در بادامزمينى محيط خاك بذر و شرايط آب و هوايى عوامل مهمى هستند كه كيفيت بذر بادام زمينى

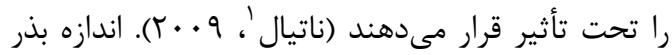
يكى از عواملى مىباشد كه از محيط تأثير يذيرفته و بلظاهر نيز قابل رؤيت ميىباشد (سلطانى ' و همكاران،

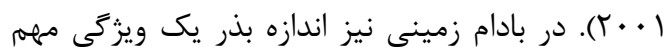

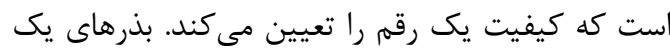

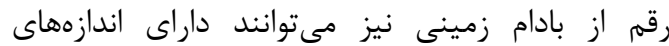
مختلفى باشند. بهطور مثال رقمهاى دانه درشت بادام

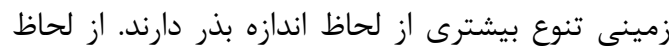
يكنواختى نيز تفاوتهايى بين ارقام بادام زمينى با اندازههاى مشابه وجود دارد (نافت بَ و همكاران، (1991).

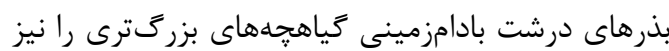
توليد مى كنند. بلطورى كه گياهجههاى بلوجود آمده از

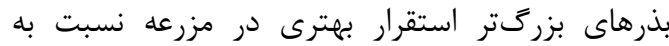

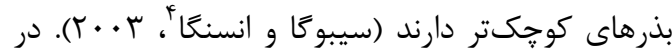
بادام زمينى بذرهاى درشتتر بهدليل داشتن مواد غذايى

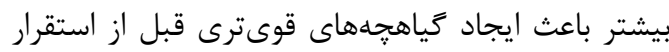

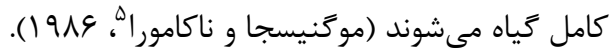
سادهترين ارزيابىها جهت تعيين كيفيت بذر با استفاده از آزمون جوانهزنى استاندارد صورت مى كيرد كه توانايى بالقوه جوانهنى بذرها را در يك توده بذرى رنى مشخص مىنمايد (ايستا؛ سو991). درعينحال استفاده بـاه

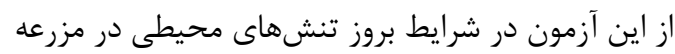

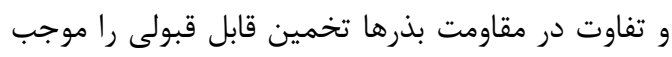
نمىشود، لذا در جنين شرايطى استفاده از آزمونهاى

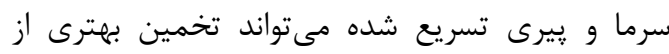

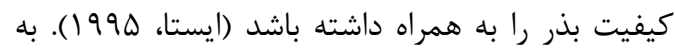
عنوان مثال افزايش دما و ر رطوبت سرعت انجام واكنشهاى شيميايى جوانهزنى را تحت تأثير قرار

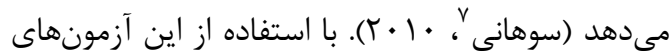
جوانهزنى پس از اعمال شرايط مختلف محيطى مىتوان

\footnotetext{
${ }^{1}$ Nautiyal

${ }^{2}$ Soltani

${ }^{3}$ Knauft

${ }^{4}$ Sibuga and Nsenga

${ }^{5}$ Mugnisjah and Nakamura

${ }^{6}$ ISTA

${ }^{7}$ Souhani
} 
ترتيب TY- و T/K متر مىباشند. ميانگين متوسط دما،

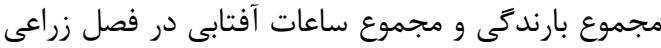

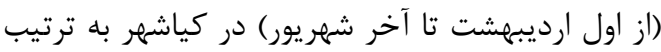

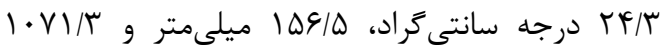
ساعت و در لاهيجان به ترتيب M/V د درجه سانتى گراد،

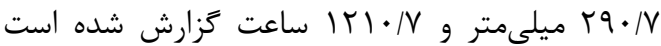

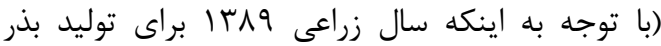
مدنظر قرار گرفته بود، از دادههاى هواشناسى اين سال

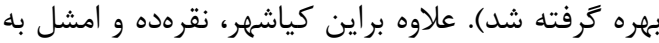
ترتيب بهعنوان جديدترين، عمدهترين و قديمىترين توليدكننده بادامزمينى در آستانه اشرفيه مىباشند كه مبناى ديخرى از تقسيمبندى مناطق در نظر گرفته شد.

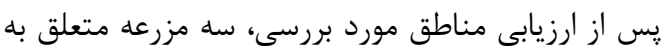
كشاورزان نمونه در كشت بادام زمينى انتخاب شدند. جهت تعيين ويزگگیىاى خاك محل آزمايش، نمونه خاك از نقاط مختلف مزرعه مورد كشت در هر

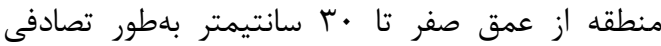
برداشت شده و از تركيب آنها نمونه مركبى تهيه

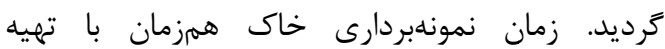
تودههاى بادام زمينى و قبل كاشت فصل زراعى جديد در اوايل بهار • وبا بود. خصوصيات فيزيكى و شيميايى نمونه خاكها در آزمايشعاه آب و و خاك دابل دانشكده كشاورزى دانشعاه آزاد اسلامى واحد رشت در در زمستان

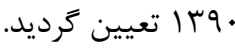

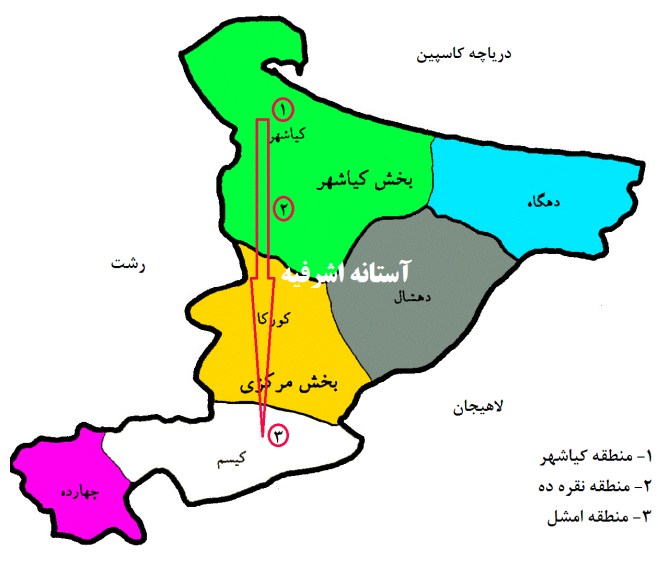

شكل ا- نقشه مناطق مورد بررسى

Figure 1. Map of areas studied
ززارش كردند كه شرايط نامساعد محيطى باعث كاهش ميزان استفاده از ذخاير بذر در فرآيند جوانهزنى گرديد.

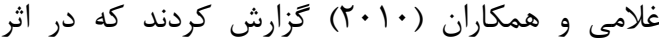

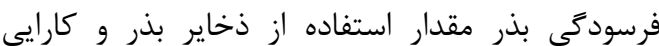
تبديل ذخاير بذر كاهش معنى دارى يافت. باتوجه به اينكه شهرستان آستانه اشرفيه بهعنوان

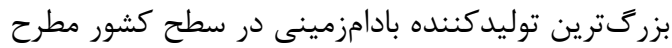
مىباشد، اما هنوز بذر مناسبى براى توليد اين محصول در منطقه وجود ندارد و بهطور عمده از محصول سال قبل كشاورزان تهيه مى گرددد. اين موضوع نيازمند ارائه راهكارى فورى براى حل اين معضل بسيار مهرم در منطقه مىباشد تا برنامهريزىهاى بلندمدت جهت توليد بذر مناسب در منطقه توسط سازمانهاى مربوطه صورت كيرد. لذا ضرورت مىيابد بخشهايى از سطح زير كشت مثان بادامزمينى در منطقه كه قابليت توليد بذر باكيفيتترى

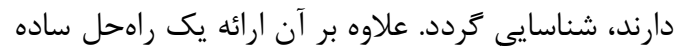

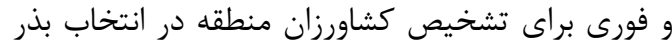
مناسب، آكاهى از خصوصيات ظاهرى بذر باكيفيت

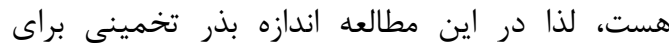
كيفيت بذر در نظر گرفته شد. در اين راستا در تحقيق حاضر به ارزيابى اثر منطقه توليد و اندازه بذر بر شاخصهاى جوانهزنى و رشد هتروتروفيك گياهجه بادام زمينى با استفاده از آزمونهاى جوانهزنى استاندارد، سرما و ييرى تسريع شده يرداخته شد.

\section{مواد و روشها شرايط مزارع نمونه}

ابتدا با استفاده از نقشه جغرافيايى (شكل ())، منطقه توليد بادامزمينى در شهرستان آستانه اشرفيه به سه قسمت نقرهده، امشل و كياشهر تقسيم گرديد. همانطور كه در شكل شماره 1 قابل مشاهده است، مناطق كياشهر، نقرهده و امشل به ترتيب در امتداد خطى از درياى خزر به سمت لاهيجان قرار دارند. لذا طبيعى است كه با فاصله گرفتن از سطح دريا، تفاوتهايى از لحاظ شرايط آب و هوايى، خصوصيات خاك و سطح

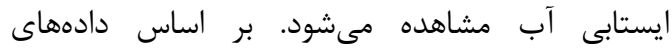
هواشناسى دو ايستخاه هواشناسى فعال در بندر كياشهر و لاهيجان، ارتفاع از سطح دريا در كياشهر و لاهيجان به 
طول رشد بوتهها كنترل علفهاى هرز نيز بلهورت دستى انجام كرفت. نمونهبردارى با حذف اثرات حاشيه-

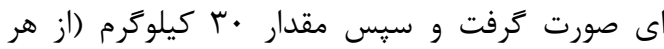

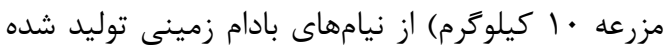

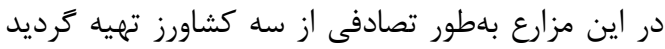
كه براى آزمونهاى مختلف بذر مورد استفاده قرار بهار

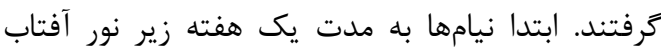
خشك شدند. با توجه به اينكه زمان استفاده از نيامها در

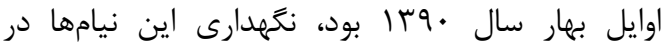

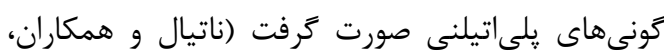
ب991). شايان ذكر است كه نمونههاى قرار كرفته در

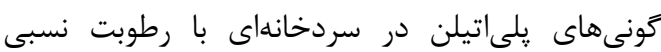

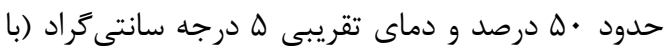
توجه به ماهيت روغنى بودن بذرهاى بادامزمينى)

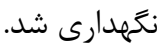

\section{بخش آزمايشَاهى}

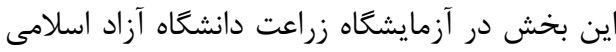
واحد رشت در اواخر سال •وجا انجام كرفت. براى انجام آزمونهاى جوانهزنى و رشد كياهجه، بذرهاى حاصل ازئ نيامهاى هر منطقه به سه دسته بزرى، متوسط و ورناي كوجكتر تقسيمبندى شدند. براى اين منظور از ترازويى

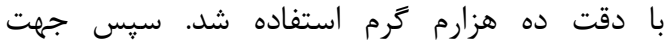

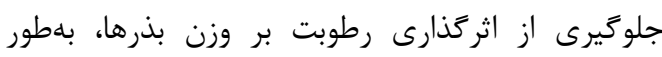
تصادفى مقدار رطوبت نمونههايى از بذر اندازهخيرى شد. هر يك از آزمونهاى انجام كرفته با استفاده از آزمايش آنداني

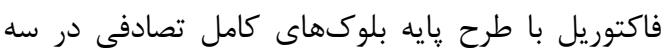
تكرار مورد بررسى قرار كرفتند. فاكتور اول منطقه توليد

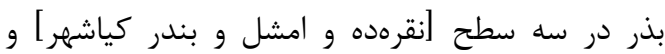

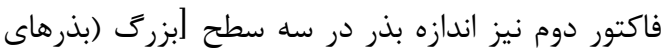

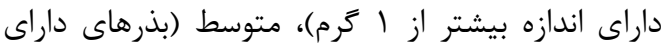

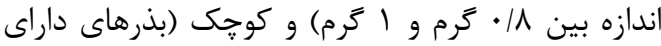

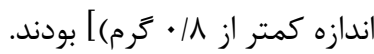

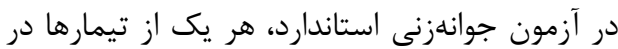

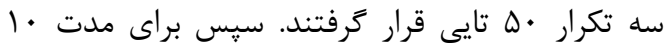

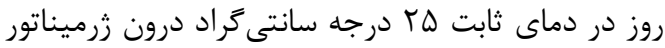

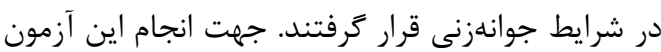
از روش جوانهزنى بين كاغذ جوانهزنى مرطوب استفاده
بافت خاكها در مزرعه نقرهده لومى شنى و در مزارع امشل و كياشهر لومى بودند و هدايت الكتريكى

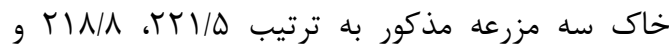
IV9/T ميكروزيمنس بر سانتيمتر به دست آمد. اسيديته خاك در سه مزرعه مورد بررسى در نقرهده،

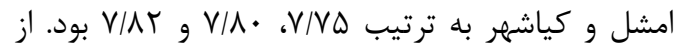
لحاظ نيتروثن كل (در نقرهده، امشل و كياشهر به ترتيب لترنيب

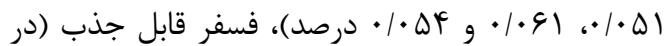

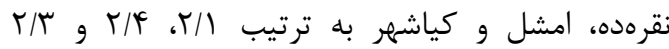
ميلى كرم بر كيلو

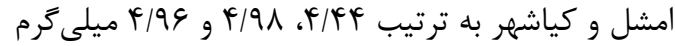

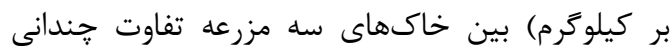

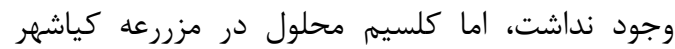

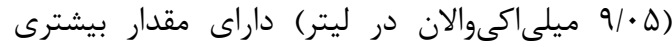

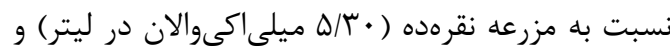
مزرعه امشل ( •ه/ه ميلى اكىوالان در ليتر) ) بودند. جهت تهيه بستر كاشت، زمين در اوايل بهار ابتدا

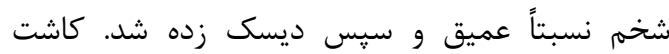

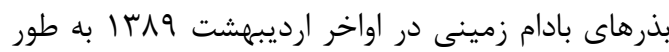
همزمان در سه مزرعه، بلصورت مسطح و در شرايط ديم (بدون آبيارى) انجام كرفت. شايان ذكر است كرده كشاورزان هر سه منطقه مورد بررسى، در زمانهان إنى

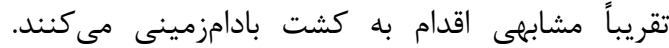
بذرهاى اوليه بادام زمينى متعلق به هر كشاورز نيز با باديا

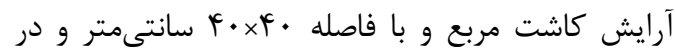
عمق ץ سانتىمترى خاك كشت شدند (بل و و همكاران،

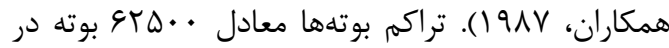
هكتار بود. در زمان كاشت مقدار نيتروزن موردنياز كياه

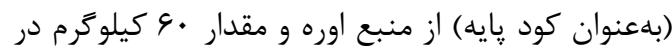
هكتار و فسفر موردنياز از منبع سويرفسفات ترييل به آنها

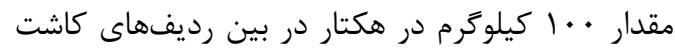

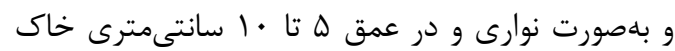
قرار داده شدند. از آنجايى كه بيشترين سطح زير كشت

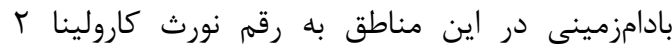
تعلق دارد، بنابراين فقط از اين رقم براى كشت و

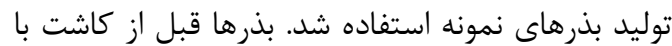
قارجكش تيرام به نسبت دو در هزار ضدعفونى شد. در

\footnotetext{
${ }^{1}$ Bell
} 
خراى آزمون رشد هتروتروفيك گياهجه، ابتدا وزن خشك اوليه بذر (ISDW) هر تيمار كه با كم كردن

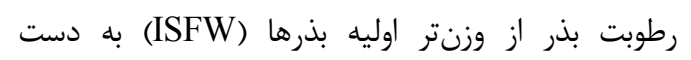

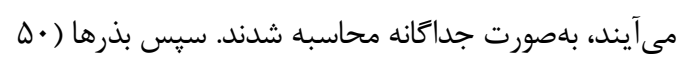

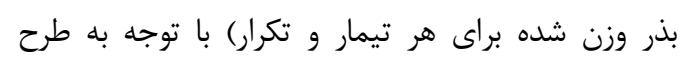

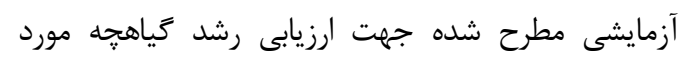

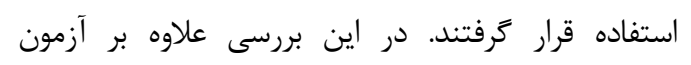

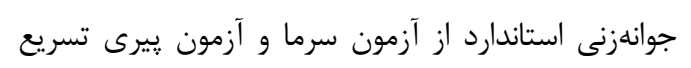

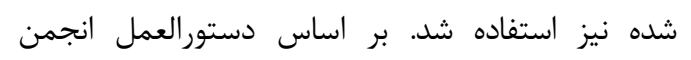

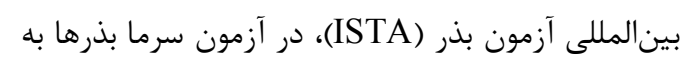

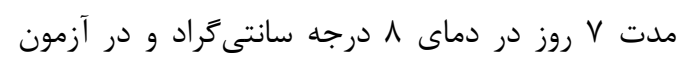

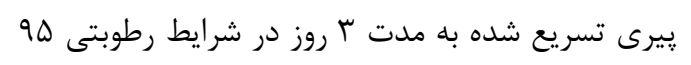

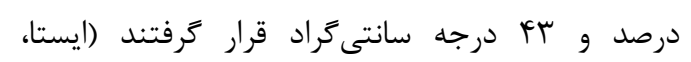

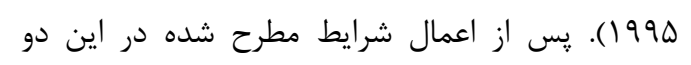

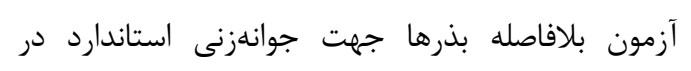

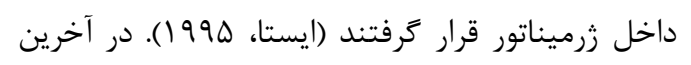

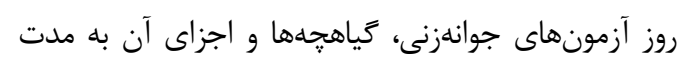
FF

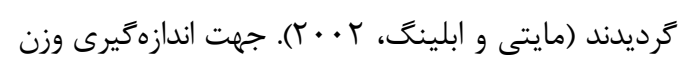

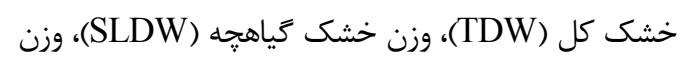

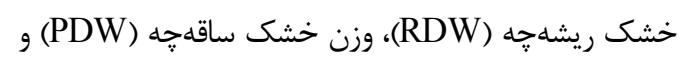

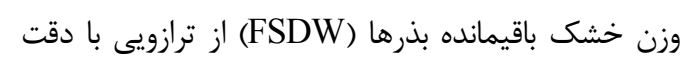

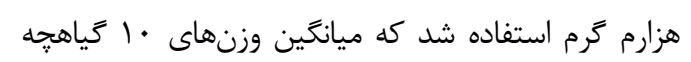
عادى براى هر واحد آزمايشى محاسبه شد. در نهايت، مقدار

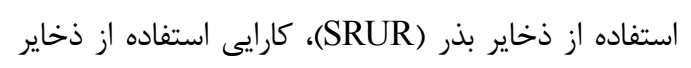

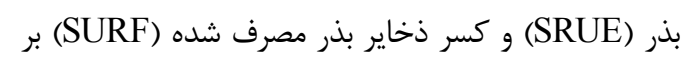

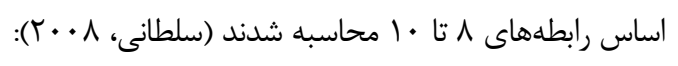
رابطه (^) مقدار استفاده از ذخاير بذر (ميلى گرم در SRUR = ISDW - FSDW هر بذر) رابطه (9) كارايى استفاده از ذخاير بذر SRUE = SLDW / SRUR

$$
\text { رابطه (• () كسر ذخاير مصرف شده بذر }
$$

SURF = SRUE / ISDW

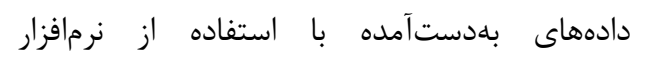

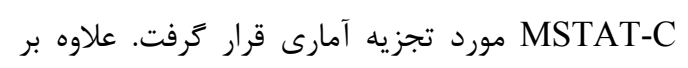

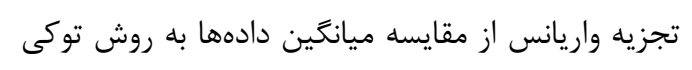
براى تحليل نتايج به دست آمده استفاده شد.
شد. ظرفهاى در نظر كرفته شده با هييوكلريت سديم

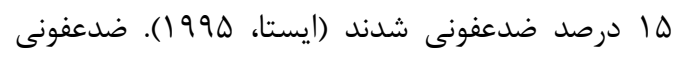

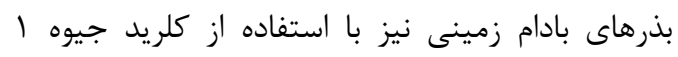

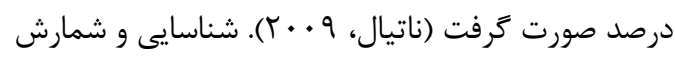

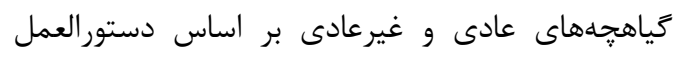

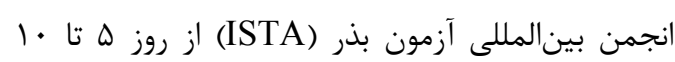

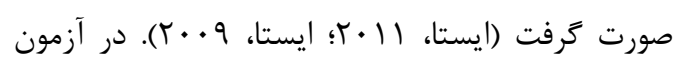

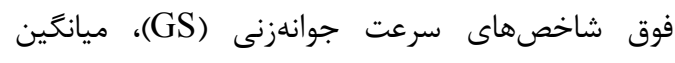

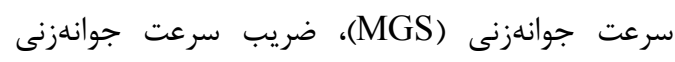
جوانون، (CGS)

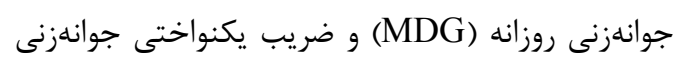
با استفاده از رابطههاى ا تا 4 (CUG)

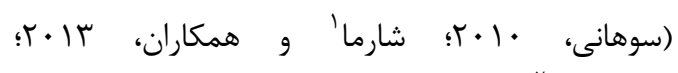

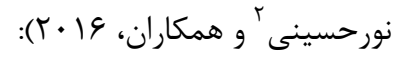

$$
\text { رابطه (1) سرعت جوانهزنى }
$$

$\mathrm{GS}=\sum(\mathrm{n} / \mathrm{t})$

$$
\begin{aligned}
& \text { رابطه (r) ميانگين سرعت جوانهزنى } \\
& \text { MGS }=\sum(\mathrm{nt}) / \sum \mathrm{n} \\
& \text { CGS }=\sum \text { n.100 / } 2 \text { (nt) } \\
& \text { رابطه (r) ضريب سرعت جوانهزنى } \\
& \mathrm{MGT}=\sum \mathrm{Dn} / \mathrm{N} \\
& \text { رابطه (f) متوسط زمان جوانهزنى } \\
& \text { رابطه (ه) متوسط جوانهزنى روزانه }
\end{aligned}
$$$$
\mathrm{MDG}=\mathrm{FGP} / \mathrm{D}
$$$$
\mathrm{MDG}=\mathrm{FGP} / \mathrm{MGT}
$$

در رابطههاى بالا n= تعداد بذر جوانهزده تا روز،

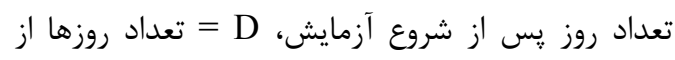

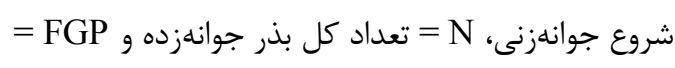

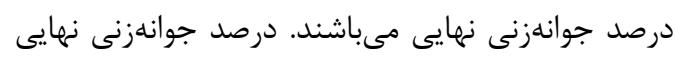

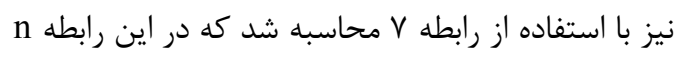
= شمار بذرهاى جوانهزده عادى و N = شمار كل بذرها ل

$$
\text { مىباشد. }
$$$$
\mathrm{FGP}=\sum \frac{\mathrm{n}}{\mathrm{N}} \times 100
$$

\footnotetext{
${ }^{1}$ Sharma

${ }^{2}$ Noorhosseini
} 
بافتهاى سبكتر مىباشد. بر اين اساس به نظر مىرسد كه لوم شنى بودن بافت خاك مزرعه انتخاب شده در

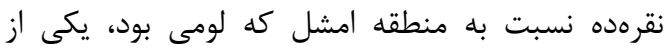

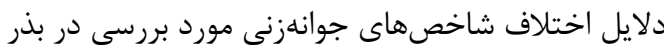
توليد شده در دو منطقه باشد. از طرف ديكر عدم تفاوت بين بافت خاك كياشهر و امشل حاكى از آن است

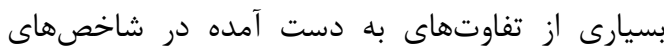
جوانهزنى دلايل متعدد ديخرى ازجمله ساير عوامل

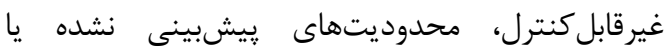
مشاهده نشده در مدير يتهاى زراعى (ازجمله بروز آفات، بيمارى و غيره) و همجنين ساير خصوصيات اندازهخيرى

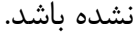

نتايج و بحث ارزيابى شاخصهاى جوانهزنى استاندارد نتايج تجزيه واريانس در آزمون جوانهزنى استاندارد

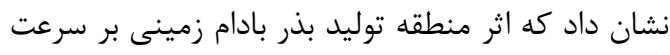
جوانهزنى و ضريب يكنواختى جوانهزنى به ترتيب در دران سطح احتمال ا درصد و ه درصد معنىدارى بود. در عين حال اثر منطقه توليد بذر بادام زمينى بر ضريب

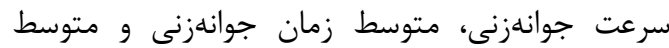
جوانهزنى روزانه معنى دار نشد (جدول (1). نتايج مقايسه

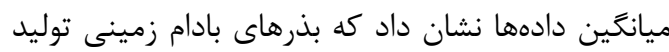
شده در منطقه امشل داراى بيشترين سرعت جوانهزنى دانى

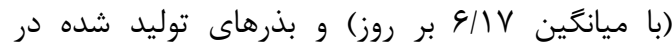
كياشهر داراى كمترين سرعت جوانهزنى (با ميانگين

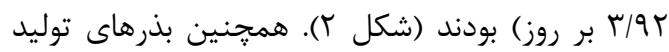
شده در امشل از ضريب يكنواختى جوانهزنى (با ميانكين

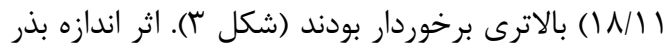
بر هيج كدام از شاخصهاى جوانهزنى مذكور معنى دار بار بارد نشد (جدول (). اثر متقابل منطقه توليد در اندازه بذر بادام زمينى بر شاخص ميانكين سرعت جوانهزنى در سطح احتمال ه درصد معنى دار شد (جدول (1). نتايج مقايسه ميانكين دادهها نشان داد كه بيشترين ميانكين

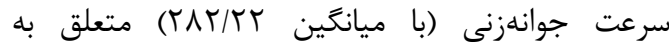
بذرهاى درشت توليد شده در منطقه امشل به دست آمد. در حالى كه بذرهاى درشت توليد شده در منطقه

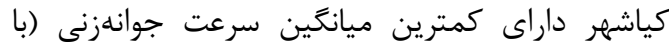

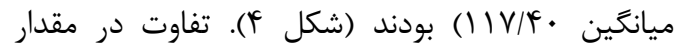
كلسيم و نيتروزن دانههاى توليد شده در مناطق مختلف از جمله عوامل مؤثر بر اختلاف شاخصهاى سرعت

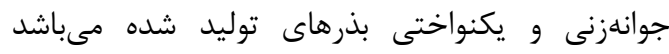

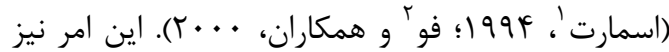
ناشى از تفاوت در مقدار كلسيم خاكهاى زمينهاى

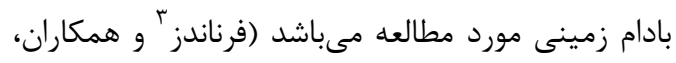

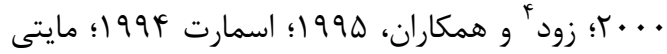

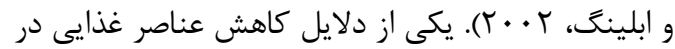
خاكهاى مناطق مختلف، شسته شدن عناصر غذايى در آنائر

\footnotetext{
${ }^{1}$ Smartt

${ }^{2} \mathrm{Fu}$

${ }^{3}$ Fernandez

${ }^{4}$ Zode
} 
جدول ا- تجزيه واريانس اثر منطقه توليد و اندازه بذر براى شاخصهاى جوانهزنى استاندارد در بادام زمينى

Table 1. Analysis of variance of production region and seed size effects on germination indices of peanut

\begin{tabular}{|c|c|c|c|c|c|c|c|}
\hline $\begin{array}{l}\text { منبع تغييرات } \\
\text { (S.O.V) }\end{array}$ & $\begin{array}{l}\text { درجادى } \\
\text { (DF) }\end{array}$ & $\begin{array}{c}\text { سرعت جوانهزنى } \\
\text { Germination } \\
\text { speed }\end{array}$ & $\begin{array}{c}\text { ميانكَين سرعزنه } \\
\text { Mean } \\
\text { Mermination } \\
\text { speed }\end{array}$ & $\begin{array}{c}\text { ضريب سرانهزنى } \\
\text { Coefficient } \\
\text { of } \\
\text { germination } \\
\text { speed }\end{array}$ & $\begin{array}{c}\text { جوانهزنى زمان } \\
\text { Mean } \\
\text { germination } \\
\text { time }\end{array}$ & $\begin{array}{l}\text { متوسط جوانهزنى روزانه } \\
\text { Mean daily } \\
\text { germination }\end{array}$ & $\begin{array}{c}\text { ضريب يكنواختى } \\
\text { Coefficient of } \\
\text { uniformity of } \\
\text { germination }\end{array}$ \\
\hline & & \multicolumn{6}{|c|}{ ميانگين مربعات (Mean of Square) } \\
\hline $\begin{array}{c}\text { تكرار } \\
\text { Replication }\end{array}$ & 2 & $2.568^{\mathrm{ns}}$ & $2037.11^{\mathrm{ns}}$ & $0.625^{\text {ns }}$ & $0.514^{\mathrm{ns}}$ & $2.246^{\mathrm{ns}}$ & $31.592^{\mathrm{ns}}$ \\
\hline $\begin{array}{c}\text { منطقه } \\
\text { Region }\end{array}$ & 2 & $11.553^{* *}$ & $25440.72^{* *}$ & $1.747^{\mathrm{ns}}$ & $0.240^{\mathrm{ns}}$ & $2.090^{\mathrm{ns}}$ & $76.192^{*}$ \\
\hline $\begin{array}{c}\text { اندازه بذر } \\
\text { Seed size }\end{array}$ & 2 & $1.655^{\mathrm{ns}}$ & $1516.85^{\mathrm{ns}}$ & $1.307^{\mathrm{ns}}$ & $0.611^{\mathrm{ns}}$ & $2.883^{\mathrm{ns}}$ & $4.457^{\mathrm{ns}}$ \\
\hline $\begin{array}{c}\text { منطقه|ندازه بذر } \\
\text { Region × Seed } \\
\text { size }\end{array}$ & 4 & $2.755^{\mathrm{ns}}$ & $2457.47^{*}$ & $4.034^{\mathrm{ns}}$ & $0.153^{\mathrm{ns}}$ & $0.807^{\mathrm{ns}}$ & $15.872^{\mathrm{ns}}$ \\
\hline $\begin{array}{l}\text { خط } \\
\text { Error }\end{array}$ & 16 & 1.964 & 732.55 & 2.901 & 0.239 & 1.803 & 18.162 \\
\hline $\begin{array}{c}\text { ضريب تغييرات (\%) } \\
\text { CV (\%) }\end{array}$ & & 28.32 & 13.33 & 10.06 & 21.09 & 13.64 & 27.85 \\
\hline
\end{tabular}

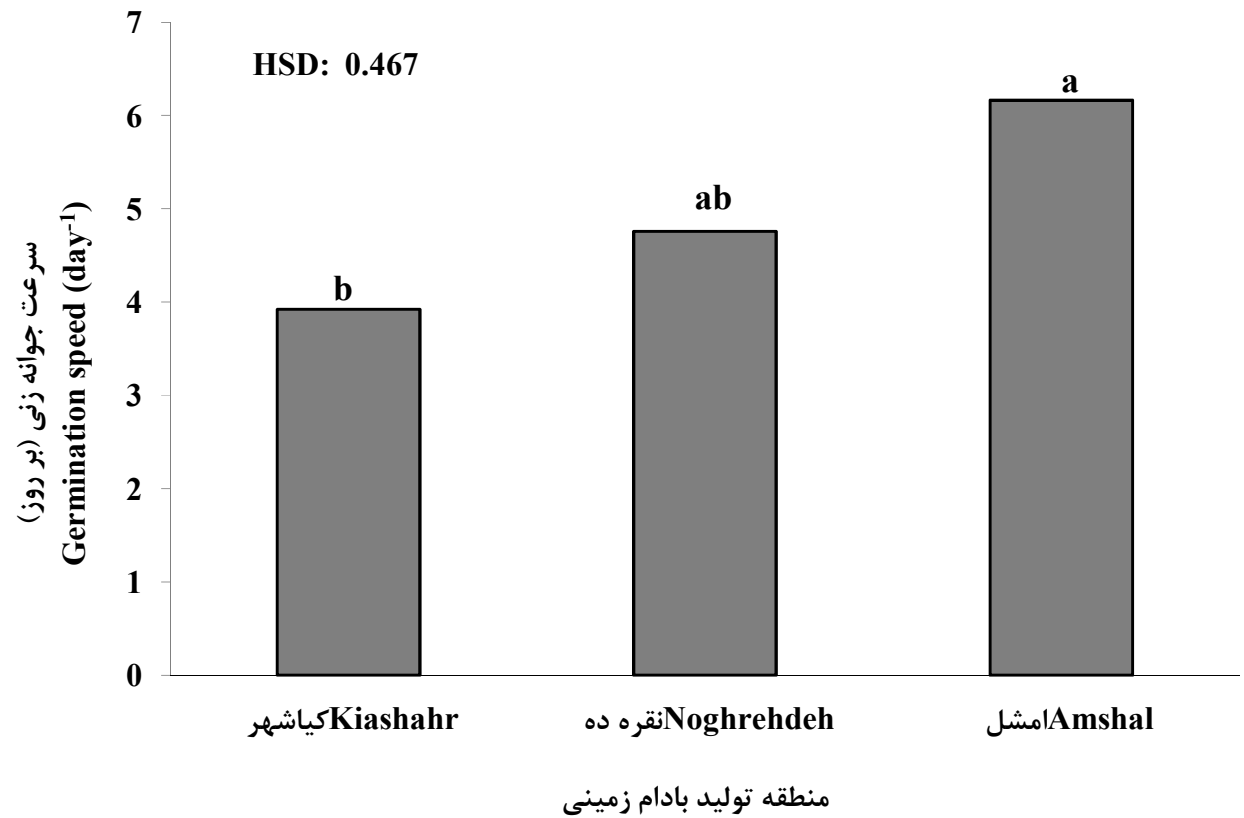

Peanut production region

شكل r - اثر منطقه توليد بر سرعت جوانهزنى (بر روز) بذر بادامزمينى. وجود حروف مشترك نشاندهنده عدم تفاوت معنى دار بين تيمارها در

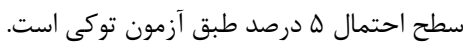

Figure 2. Effect of production region on the Germination Speed (day ${ }^{-1}$ ) of peanut seed. Means followed by similar letters show not significant difference based on Tukey Test at 5\% error probability. 


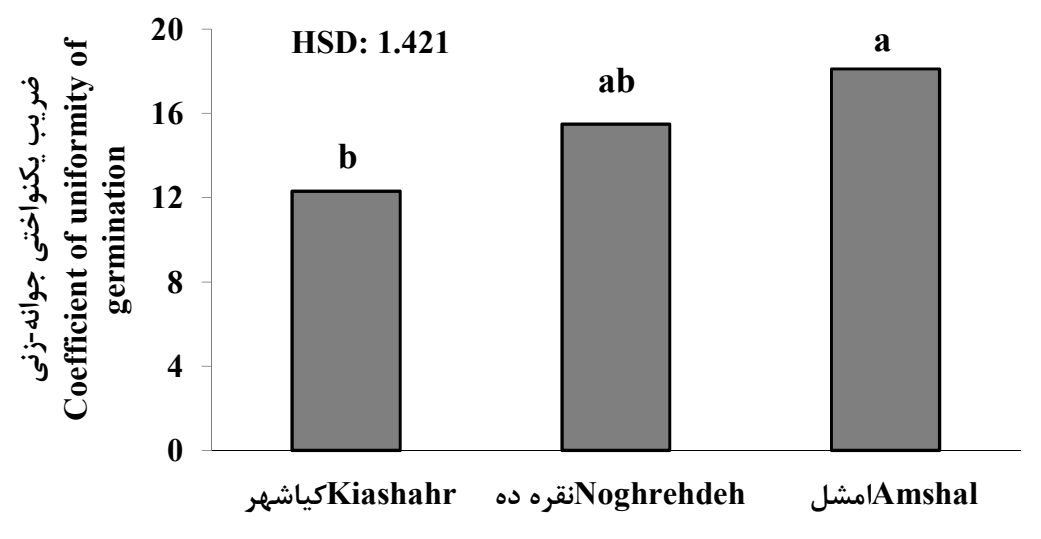

منطقه توليد بادام زمينى

Peanut production region

شكل س - اثر منطقه توليد بر ضريب يكنواختى جوانهزنى بذر بادامزمينى. وجود حروف مشترك نشاندهنده عدم تفاوت معنىدار بين تيمارها در سطح احتمال ه درصد طبق آزمون توكى است.

Figure 3. Effect of production region on Coefficient of Uniformity of Germination of peanut seed. Means followed by similar letters show no significant difference based on Tukey Test at 5\% error probability.

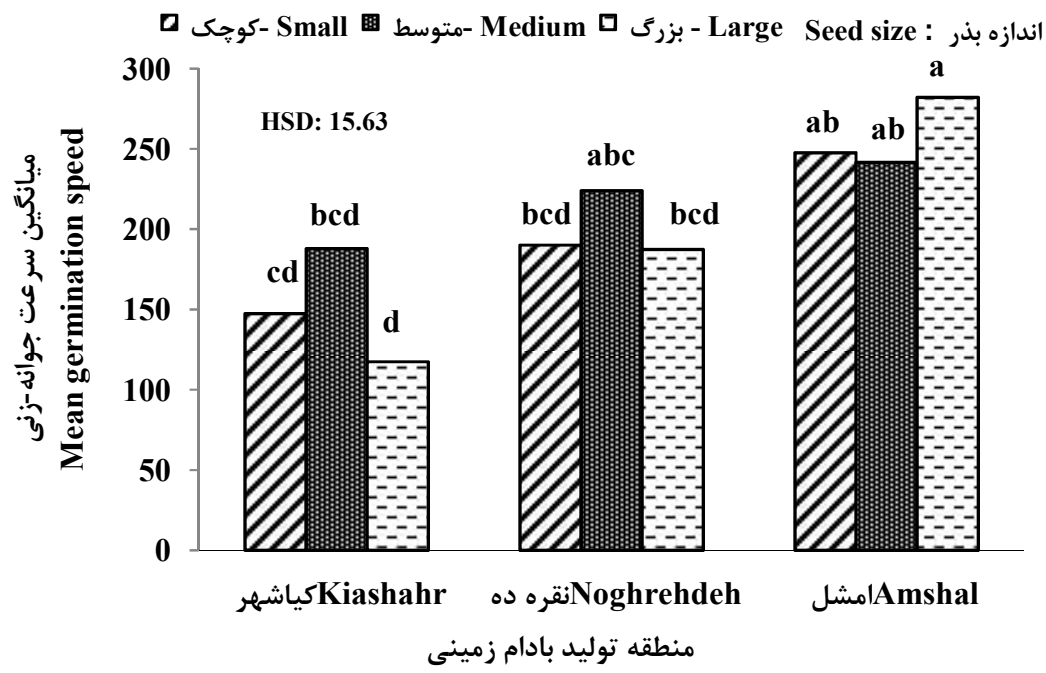

Peanut production region

شكل F- اثر تيمارهاى منطقه توليد و اندازه بذر بر ميانكين سرعت جوانهزنى بذر بادامزمينى. وجود حروف مشترك نشاندهنده عدم تفاوت معنى -

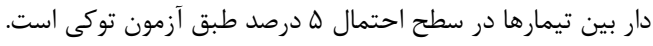

Figure 4. Effect of production region and seed size treatments on Mean Germination Speed of peanut seed. Means followed by similar letters show no significant difference based on Tukey Test at $5 \%$ error probability.

درصد معنى دار بود. اثر اندازه بذر بر يارامترهاى مقدار

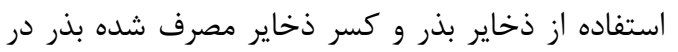

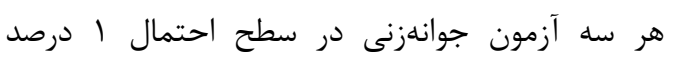

معنى دار بود. اثر متقابل منطقه توليد و اندازه بذر بر سور
ارزيابى رشد هتروتروفيك گياهجه

نتايج تجزيه واريانس نشان داد كه اثر منطقه توليد

بر مقدار استفاده از ذخاير بذر در آزمونهاى جوانه

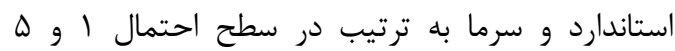


كاهش بنيه كياهجه را سبب شود (اسمارت، 999)؛

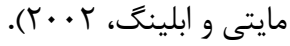

نتايج تجزيه واريانس وزن خشك كل كياهجه

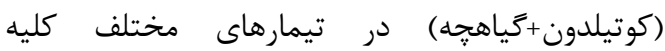
آزمونهاى بذر نشان داد كه اثر اندازه بذر بر وزن خشك دياري كل بسيار معنىدار بود. اثر متقابل منطقه و اندازه بذر دان دان

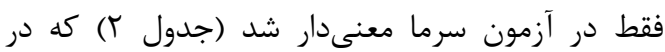
ميان بذرهاى درشت، كمترين وزن خشك كل مربوط به آنه كياشهر بود (شكل V-الف). بهطور كلى وزن خشك كل دين

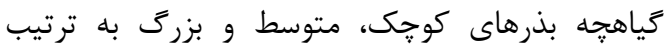

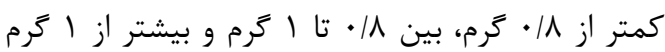

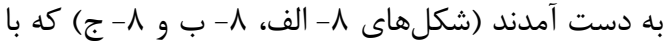
اندكى كاهش همسو با وزن اوليه بذرهاى دستهبندى

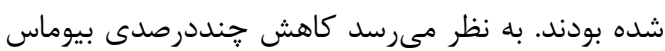
كل بذرها نسبت به وزن اوليه بذرها مربوط به حذف حذف بذاند

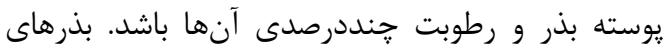

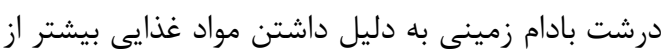
جمله كلسيم كياهجههاى قوىترى را را ايجاد مى كنند

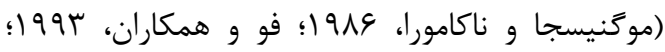

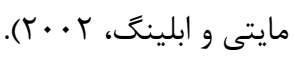

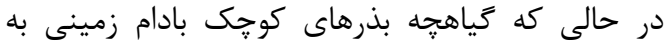
دليل كم شدن وزن خشك ريشه

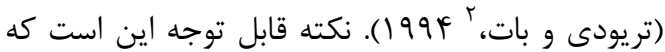
مقدار كلسيم خاك بر اندازه دانههاى توليد شده نيز

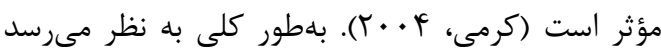

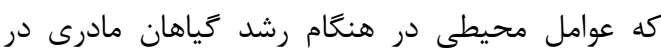

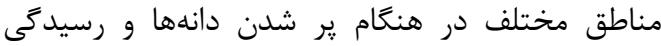

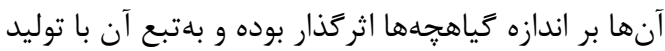
بذرهاى درشتتر كياهجههاى بزركترى را به همراه داشتند.

\footnotetext{
${ }^{2}$ Trivedi and Bhatt
}

هيجكدام از يارامترهاى مورد بررسى معنىدار نشد

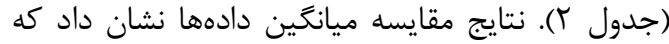
بيشترين مقدار استفاده از ذخاير بذر در منطقه امشل

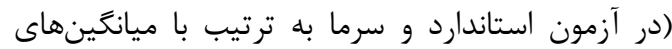

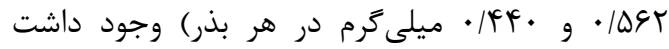
(شكل ه). همجنين بذرهاى بزرى بيشترين مقدار استفاده از ذخاير بذر (در آزمونهاى استاندارد، سرما و

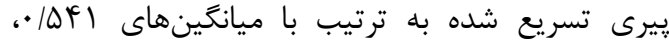

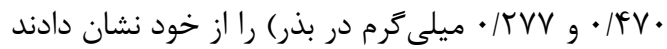

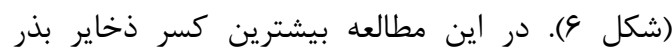
مصرف شده در بادام زمينى (در آزمونهاى استاندارد، سرما و يِيرى تسريع شده به ترتيب با ميانگَينهاى

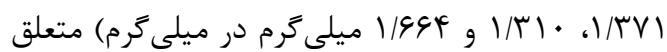
به بذرهاى كورِ بود (شكل لاب). بذرهاى درشت بادام زمينى به دليل داشتن مواد غذايى بيشتر از جمله باد باد باد باد

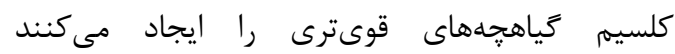

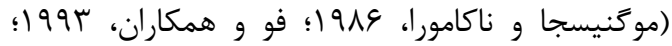

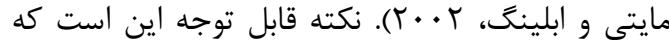

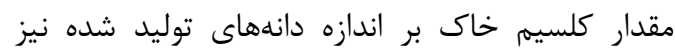

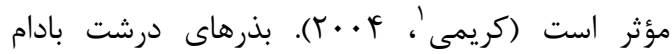
زمينى داراى عناصر ذخيرهاى بيشترى مىباشند كه علاوه بر افزايش وزن خشك كياهجه و بنيه كياهجه، بوتههاى حاصل از آنها رشد بيشتر و عملكرد بالاترى ران إنا

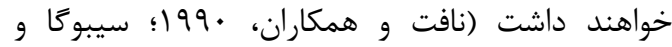

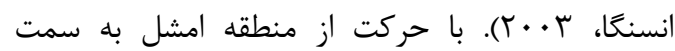
نقرهده و كياشهر، بذرهاى توليد شده وزن خشك كياهجه كمترى را نشان دادند. از اين لحاظ علاوه بر تفاوت در درد

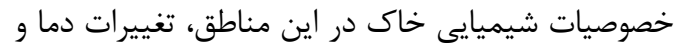

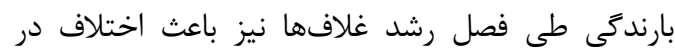
جذب عناصر آنها مىشود. بهطورى كه به نظر مىرسد

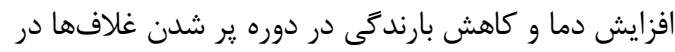

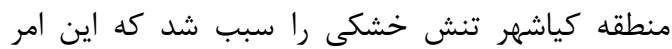

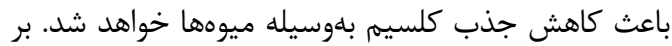
اساس بررسىهاى كذشته، كاهش كلسيم در بذرهاى توليد شده نيز مىتواند دليلى بر كاهش وزن خشى خدائ كياهجه حاصل بذرهاى بادام زمينى باشد و در در نتيجه

\footnotetext{
${ }^{1}$ Karimi
} 

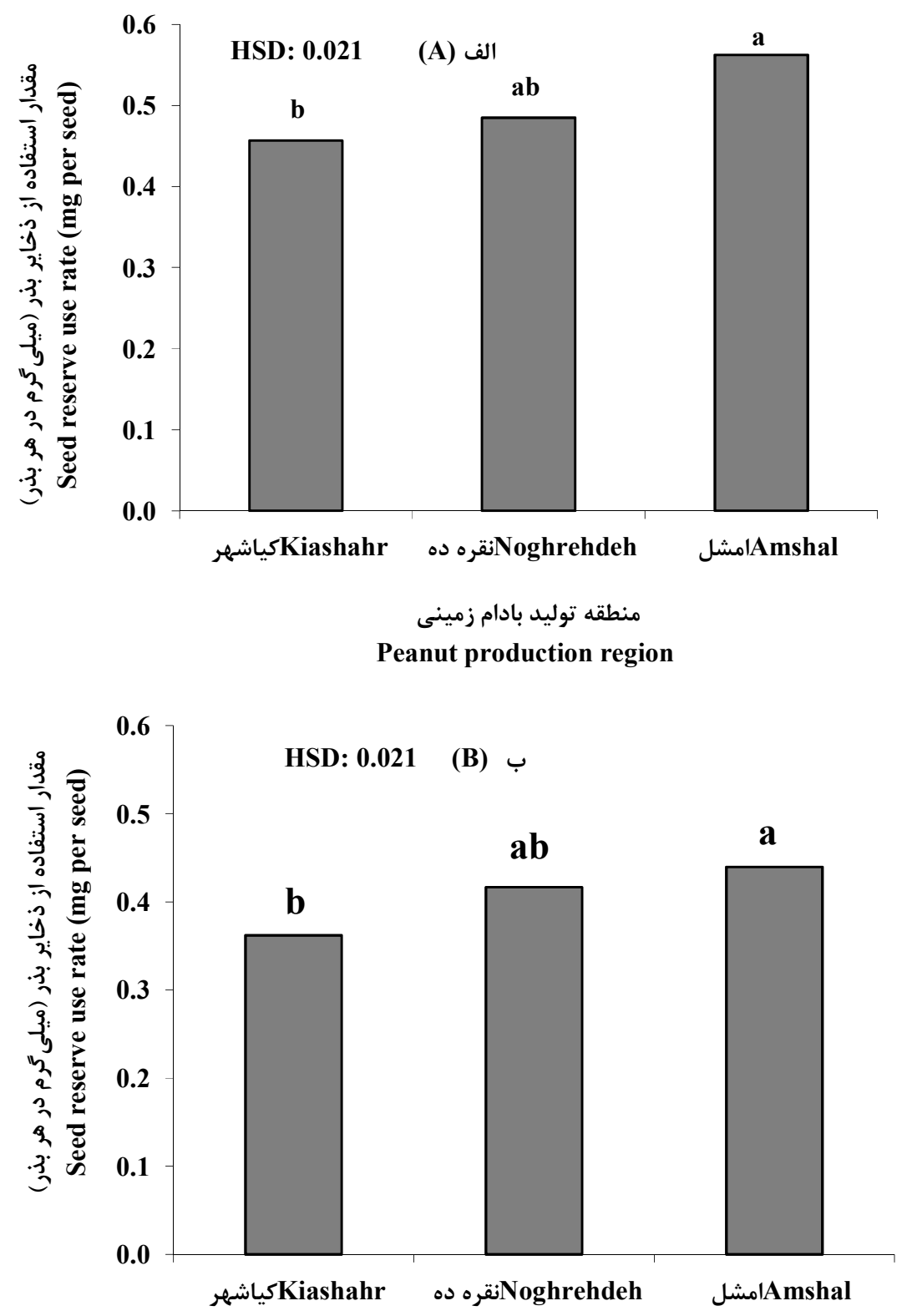

\footnotetext{
منطقه توليد بادام زمينى

Peanut production region
}

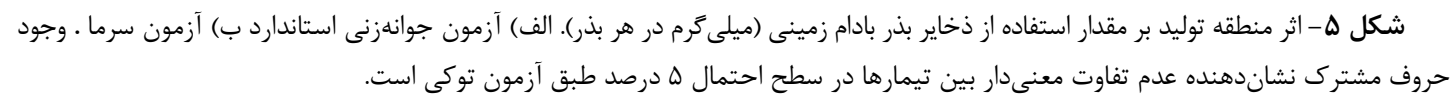
Figure 5. Effect of production region on seed reserve use rate of peanut (mg per seed). Standard germination test (A) and Cold test (B). Means followed by similar letters show no significant difference based on Tukey Test at $5 \%$ error probability. 
جدول r- تجزيه واريانس اثر منطقه توليد و اندازه بذر بر رشد هتروتروفيك كياهجه بادام زمينى

Table 2. Analysis of variance of production region and seed size effects on heterotrophic growth of peanut seedlings

\begin{tabular}{|c|c|c|c|c|c|c|c|c|c|c|}
\hline \multirow{3}{*}{$\begin{array}{l}\text { منبع تغييرات } \\
\text { (S.O.V) }\end{array}$} & \multirow{3}{*}{$\begin{array}{l}\text { آزادى } \\
\text { (DF) }\end{array}$} & \multicolumn{3}{|c|}{$\begin{array}{c}\text { مقدار استفاده از ذخاير بذر } \\
\text { Seed reserve use rate }\end{array}$} & \multicolumn{3}{|c|}{$\begin{array}{c}\text { كارايى استفاده از ذخاير بذر } \\
\text { Seed reserve utilization } \\
\text { efficiency }\end{array}$} & \multicolumn{3}{|c|}{$\begin{array}{c}\text { كسر ذخاير بذر مصرف شده } \\
\text { Seed use reserve fraction }\end{array}$} \\
\hline & & $\begin{array}{c}\text { استاندارد } \\
\text { Standard }\end{array}$ & 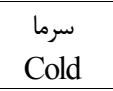 & $\begin{array}{c}\text { ي } \\
\text { Aging }\end{array}$ & $\begin{array}{c}\text { استاندارد } \\
\text { Standard }\end{array}$ & 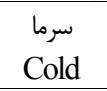 & $\begin{array}{c}\text { ي } \\
\text { Aging } \\
\end{array}$ & $\begin{array}{c}\text { استاندارد } \\
\text { Standard } \\
\end{array}$ & $\begin{array}{l}\text { سرما } \\
\text { Cold }\end{array}$ & 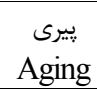 \\
\hline & & \multicolumn{9}{|c|}{ ميانگين مربعات (Mean squares) } \\
\hline $\begin{array}{c}\text { تكرار } \\
\text { Replication }\end{array}$ & 2 & $0.001^{\mathrm{ns}}$ & $0.002^{\mathrm{ns}}$ & $0.001^{\mathrm{ns}}$ & $0.001^{\mathrm{ns}}$ & $0.005^{\mathrm{ns}}$ & $0.002^{\mathrm{ns}}$ & $0.003^{\mathrm{ns}}$ & $0.009^{\mathrm{ns}}$ & $0.001^{\mathrm{ns}}$ \\
\hline $\begin{array}{l}\text { منطق } \\
\text { Region }\end{array}$ & 2 & $0.027^{* *}$ & $0.014^{*}$ & $0.001^{\mathrm{ns}}$ & $0.004^{\mathrm{ns}}$ & $0.010^{\mathrm{ns}}$ & $0.076^{\text {ns }}$ & $0.002^{\mathrm{ns}}$ & $0.045^{\mathrm{ns}}$ & $0.106^{\mathrm{ns}}$ \\
\hline $\begin{array}{c}\text { اندازه بذر } \\
\text { Seed Size }\end{array}$ & 2 & $0.026^{* *}$ & $0.030^{* *}$ & $0.022^{* *}$ & $0.009^{\mathrm{ns}}$ & $0.001^{\mathrm{ns}}$ & $0.211^{\mathrm{ns}}$ & $0.719^{* *}$ & $0.550^{* *}$ & $1.831^{* *}$ \\
\hline $\begin{array}{l}\text { منطقd×انسازه بذر } \\
\text { Region× Seed } \\
\text { Size }\end{array}$ & 4 & $0.007^{\mathrm{ns}}$ & $0.008^{\mathrm{ns}}$ & $0.005^{\mathrm{ns}}$ & $0.011^{\mathrm{ns}}$ & $0.028^{\mathrm{ns}}$ & $0.140^{\text {ns }}$ & $0.017^{\mathrm{ns}}$ & $0.026^{\mathrm{ns}}$ & $0.173^{\mathrm{ns}}$ \\
\hline $\begin{array}{l}\text { خ } \\
\text { Error }\end{array}$ & 16 & 0.004 & 0.004 & 0.003 & 0.006 & 0.011 & 0.105 & 0.008 & 0.016 & 0.148 \\
\hline $\begin{array}{l}\text { ضريب تغييرات (/) } \\
\text { CV (\%) }\end{array}$ & & 11.83 & 15.91 & 26.59 & 8.40 & 11.39 & 22.83 & 8.20 & 12.07 & 22.97 \\
\hline
\end{tabular}

ادامه جدول r-

Continued Table 2.

\begin{tabular}{|c|c|c|c|c|c|c|c|c|c|c|}
\hline \multirow{3}{*}{$\begin{array}{l}\text { منبع تغييرات } \\
\text { (S.O.V) }\end{array}$} & \multirow{3}{*}{$\begin{array}{l}\text { آزادى درجه } \\
\text { (DF) }\end{array}$} & \multicolumn{3}{|c|}{$\begin{array}{c}\text { وزن خشك كل كياهُه } \\
\text { Seedling dry weight }\end{array}$} & \multicolumn{3}{|c|}{$\begin{array}{c}\text { وزن خشك باقيمانده بذرها } \\
\text { Fragment seed dry weight }\end{array}$} & \multicolumn{3}{|c|}{ 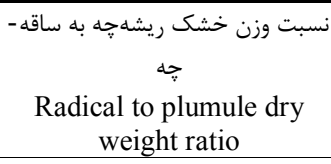 } \\
\hline & & $\begin{array}{c}\text { استاندارد } \\
\text { Standard }\end{array}$ & $\begin{array}{l}\text { سرما } \\
\text { Cold }\end{array}$ & $\begin{array}{l}\text { يpز } \\
\text { Aging }\end{array}$ & $\begin{array}{c}\text { استاندارد } \\
\text { Standard }\end{array}$ & $\begin{array}{l}\text { سرما } \\
\text { Cold }\end{array}$ & $\begin{array}{c}\text { يُر } \\
\text { Aging }\end{array}$ & $\begin{array}{l}\text { Standar } \\
\text { d } \\
\end{array}$ & 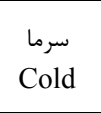 & $\begin{array}{c}\text { بيرى } \\
\text { Aging }\end{array}$ \\
\hline & & \multicolumn{9}{|c|}{ ميانكَين مربعات (Mean squares) } \\
\hline $\begin{array}{c}\text { تكرار } \\
\text { Replication }\end{array}$ & 2 & $619.11^{\mathrm{ns}}$ & $606.62^{\mathrm{ns}}$ & $671.44^{\mathrm{ns}}$ & $215.44^{\mathrm{ns}}$ & $668.97^{\mathrm{ns}}$ & $878.18^{\mathrm{ns}}$ & $0.002^{\mathrm{ns}}$ & $0.005^{\mathrm{ns}}$ & $0.004^{\mathrm{ns}}$ \\
\hline $\begin{array}{c}\text { منطقه } \\
\text { Region }\end{array}$ & 2 & $10621.00^{\mathrm{ns}}$ & $1511.03^{\mathrm{ns}}$ & $9605.97^{\text {ns }}$ & $6988.78^{\mathrm{ns}}$ & $2615.79^{\mathrm{ns}}$ & $11344.39^{\mathrm{ns}}$ & $0.006^{\mathrm{ns}}$ & $0.039^{* *}$ & $0.021^{* *}$ \\
\hline $\begin{array}{c}\text { اندازه بذر } \\
\text { Seed Size }\end{array}$ & 2 & $307688.44^{* *}$ & $330557.51^{* *}$ & $266802.94^{* *}$ & $207790.33^{* *}$ & $188311.49^{* *}$ & $229933.85^{* *}$ & $0.008^{\mathrm{ns}}$ & $0.009^{\mathrm{ns}}$ & $0.021^{* *}$ \\
\hline $\begin{array}{l}\text { منطقd×اندازه بذر } \\
\text { Region × Seed } \\
\text { Size }\end{array}$ & 4 & $4169.94^{\mathrm{ns}}$ & $9240.76^{* *}$ & $6652.99^{\mathrm{ns}}$ & $6691.28^{\mathrm{ns}}$ & $10885.64^{*}$ & $3403.14^{\mathrm{ns}}$ & $0.009^{\mathrm{ns}}$ & $0.011^{*}$ & $0.030^{* *}$ \\
\hline $\begin{array}{l}\text { خ } \\
\text { Error }\end{array}$ & 16 & 2445.57 & 1309.83 & 3028.64 & 3864.36 & 3420.86 & 3978.23 & 0.004 & 0.004 & 0.002 \\
\hline $\begin{array}{c}\text { ضريب تغييرات (\%) } \\
\text { CV (\%) }\end{array}$ & & 5.78 & 4.24 & 6.26 & 15.74 & 11.93 & 9.31 & 10.57 & 21.12 & 10.09 \\
\hline
\end{tabular}



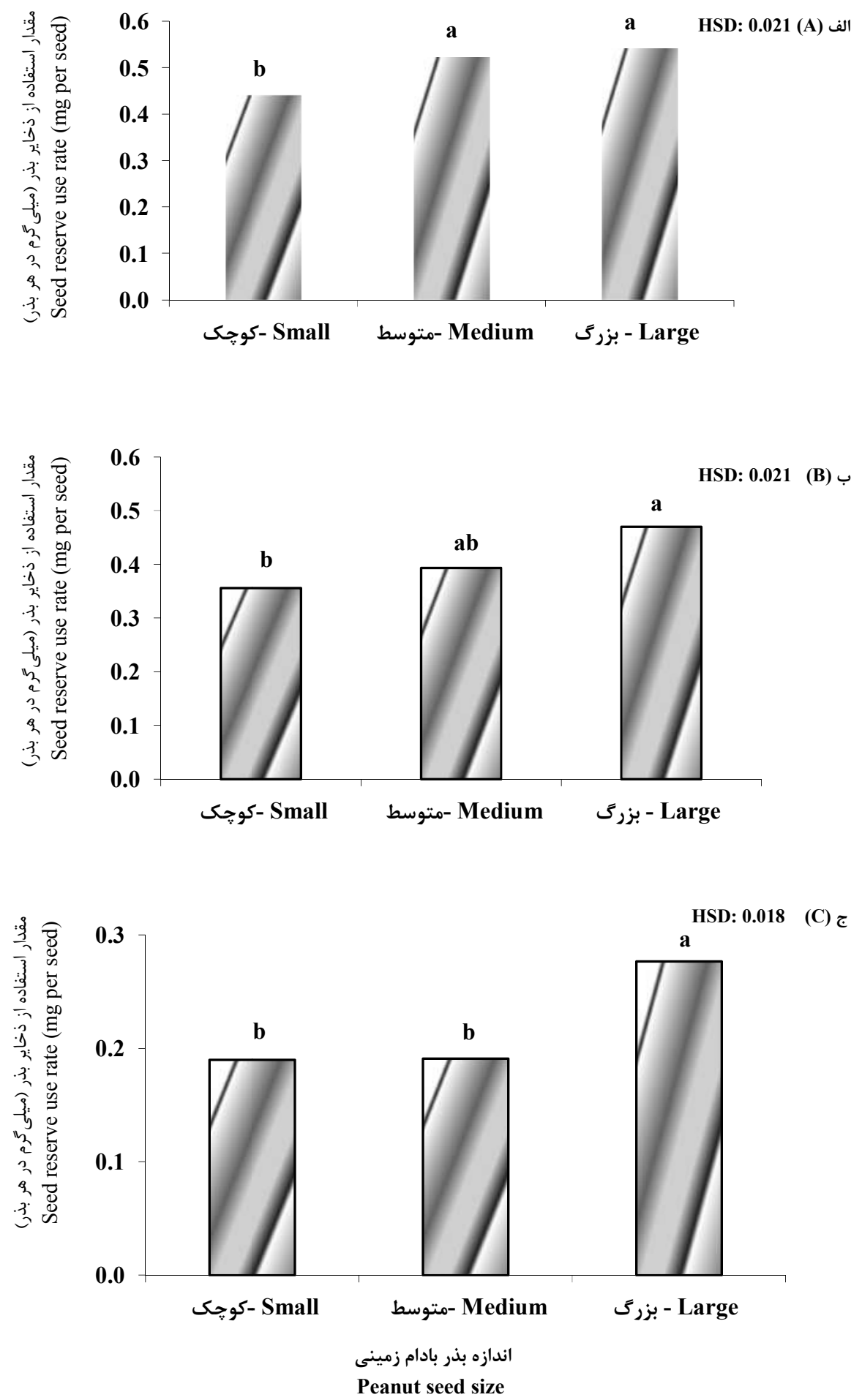

شكل \&- اثر اندازه بذر بر مقدار استفاده از ذخاير بذر بادامزمينى (ميلى

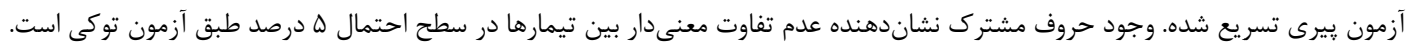

Figure 6. Effect of seed size on seed reserve use rate of peanut (mg per seed). Standard germination test (A), Cold test (B) and Accelerated aging test (C). Means followed by similar letters show no significant difference based on Tukey Test at 5\% error probability. 

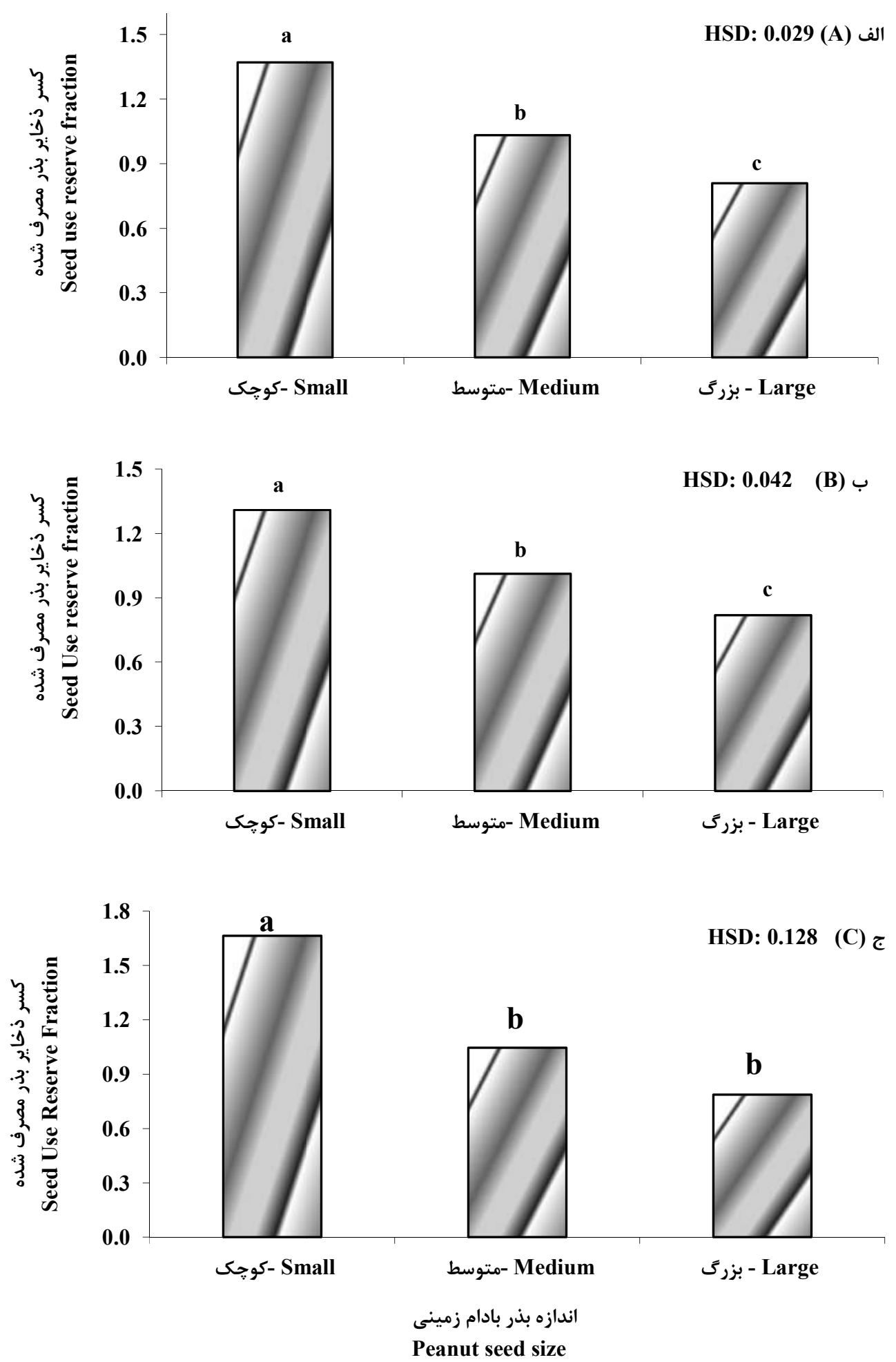

$$
\begin{aligned}
& \text { شكل V- اثر اندازه بذر بر كسر ذخاير بذر مصرف شده بادامزمينى. الف) آزمون جوانهزنى استاندارد، ب) آزمون سرماو ج) آزمون يِيرى تسريع }
\end{aligned}
$$

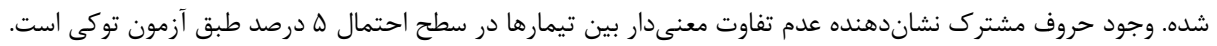

Figure 7. Effect of seed size on seed use reserve fraction of peanut. Standard germination test (A), Cold test (B) and Accelerated aging test (C). Means followed by similar letters show no significant difference based on Tukey Test at 5\% error probability. 

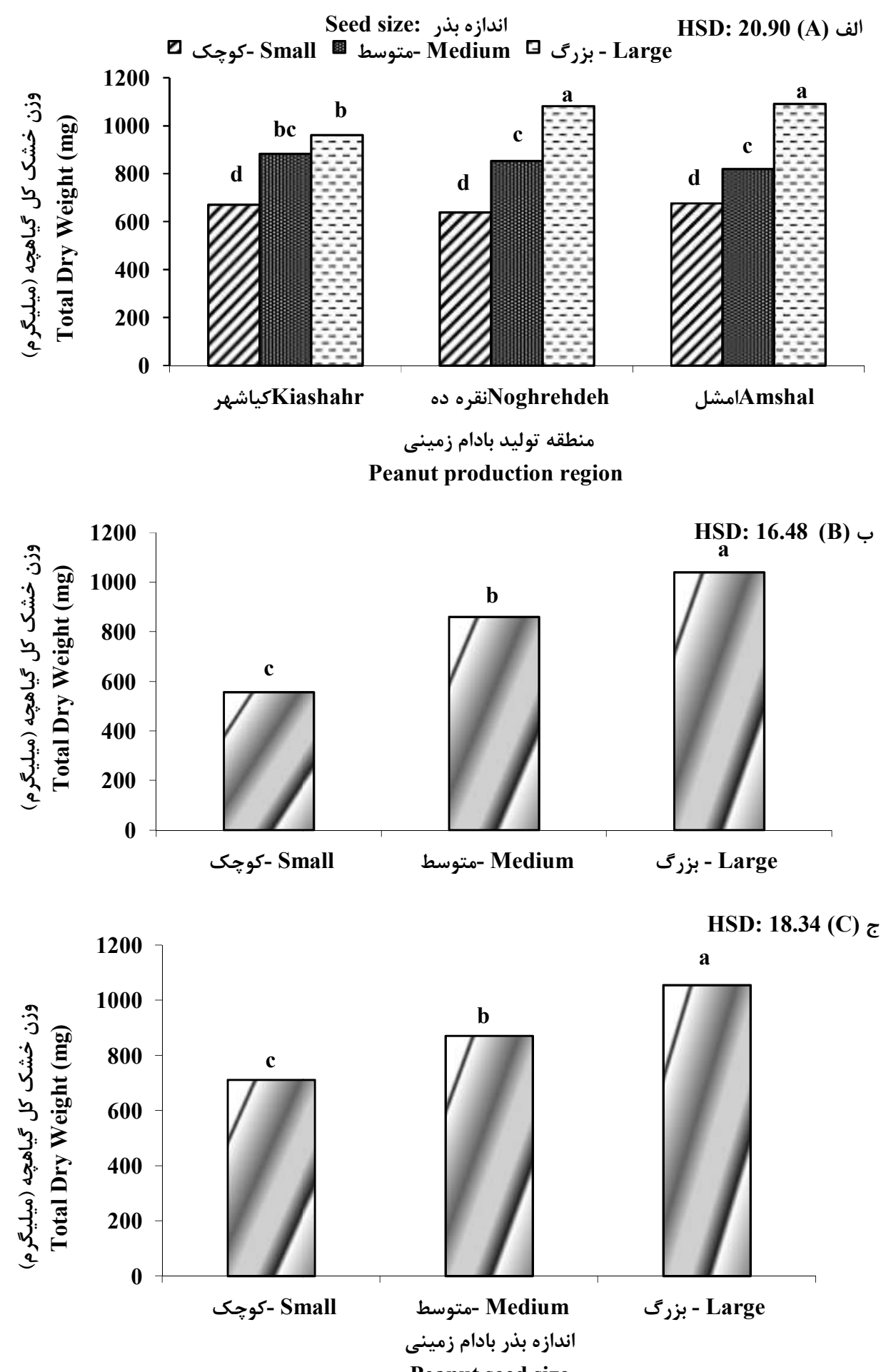

شكل 1- اثر تيمارهاى منطقه توليد و اندازه بذر بادام زمينى بر وزن خشك كل كياهجه. الف) آزمون سرما، ب) آزمون جوانهزنى

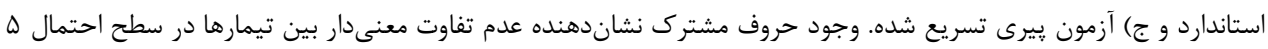
درصد طبق آزمون توكى است.

Figure 8. Effect of production region and seed size on the seedling dry weight of peanut. Cold test (A), Standard germination test (B) and Accelerated aging test (C). Means followed by similar letters show no significant difference based on Tukey Test at $5 \%$ error probability. 
منطقه كياشهر مشاهده شد (شكل • ا-الف). در حالى

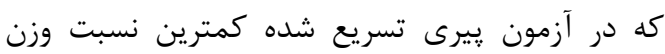

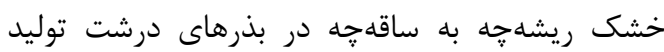

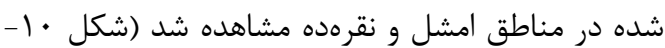
تريودى و بات (1994) با بررسى بذرهاى سنگين،

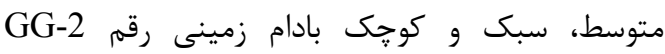

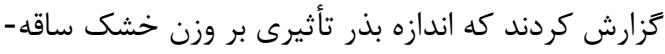

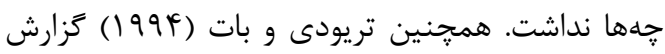
كردند كه وزن خشك ريشهجه در بذرهاى كوجى و خروكيده بادام زمينى به مقدار قابل توجهى كمتر از

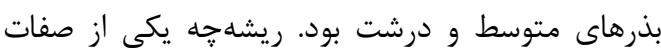

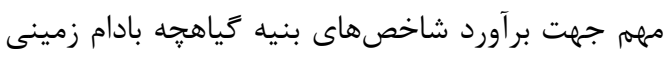
مىباشد كه در بسيارى از مطالعات مورد استفاده قرار

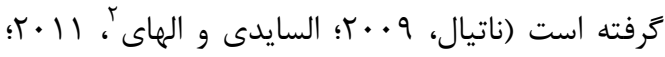

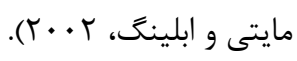

\footnotetext{
${ }^{2}$ El-Saidy and El-Hai
}

نتايج آزمونهاى مختلف جوانهزنى نشان داد كه بين اندازهاى مختلف بذر از لحاظ وزن خشك باقيمانده بذرها اختلاف بسيار معنىدارى وجود داشت (جدول كار ).

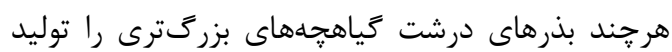

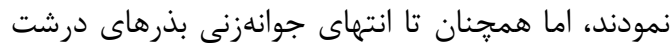

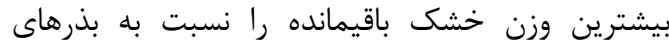

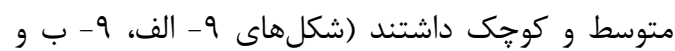
9- ج). نكته قابل توجه در آزمون جوانهزنى استاندارد

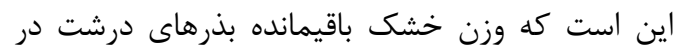

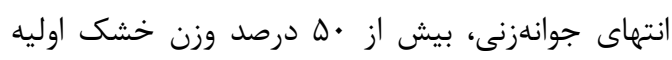

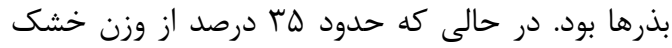

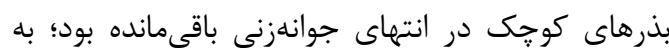

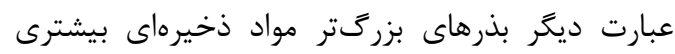

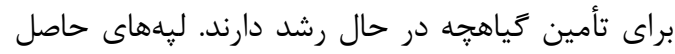

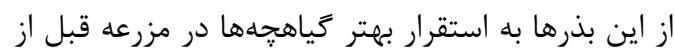

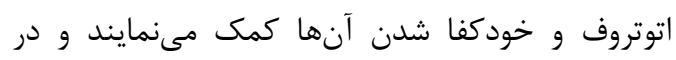

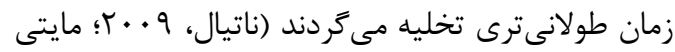

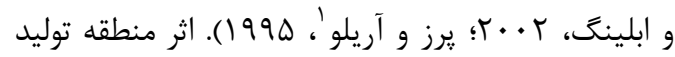

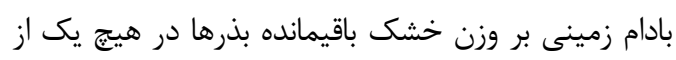
آزمونها معنى دار نبود اما در آزمون سرما اثر متقابل منطقة

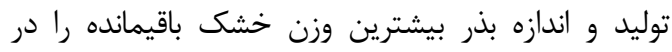

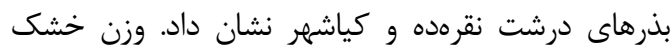
باقيمانده از بذرهاى كوخك در حالى دالى داراى كمترين مقدار

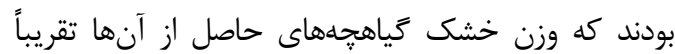

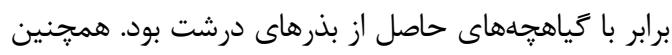

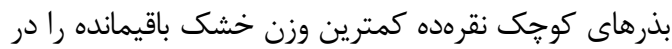
انتهاى جوانهزنى داشتند (شكل 9-الف). در آزمون جوانهزنى استاندارد، نتايج تجزيه واندئ واريانس

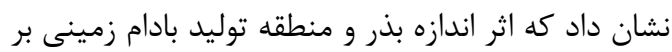
نسبت وزن خشك ريشه קه به ساقه ته معنى دار نبود. اثر

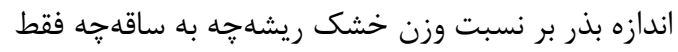
در آزمون بيرى تسريع شده معنى دار نشد. در عين حال

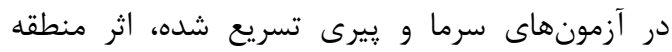

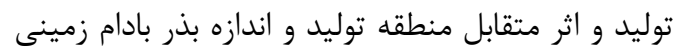
بر نسبت وزن خشك ريشهحه به ساقه (جدول r). در آزمون سرما كمترين نسبت وزن خشك

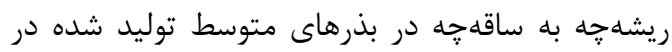

\footnotetext{
${ }^{1}$ Perez and Aryoello
} 

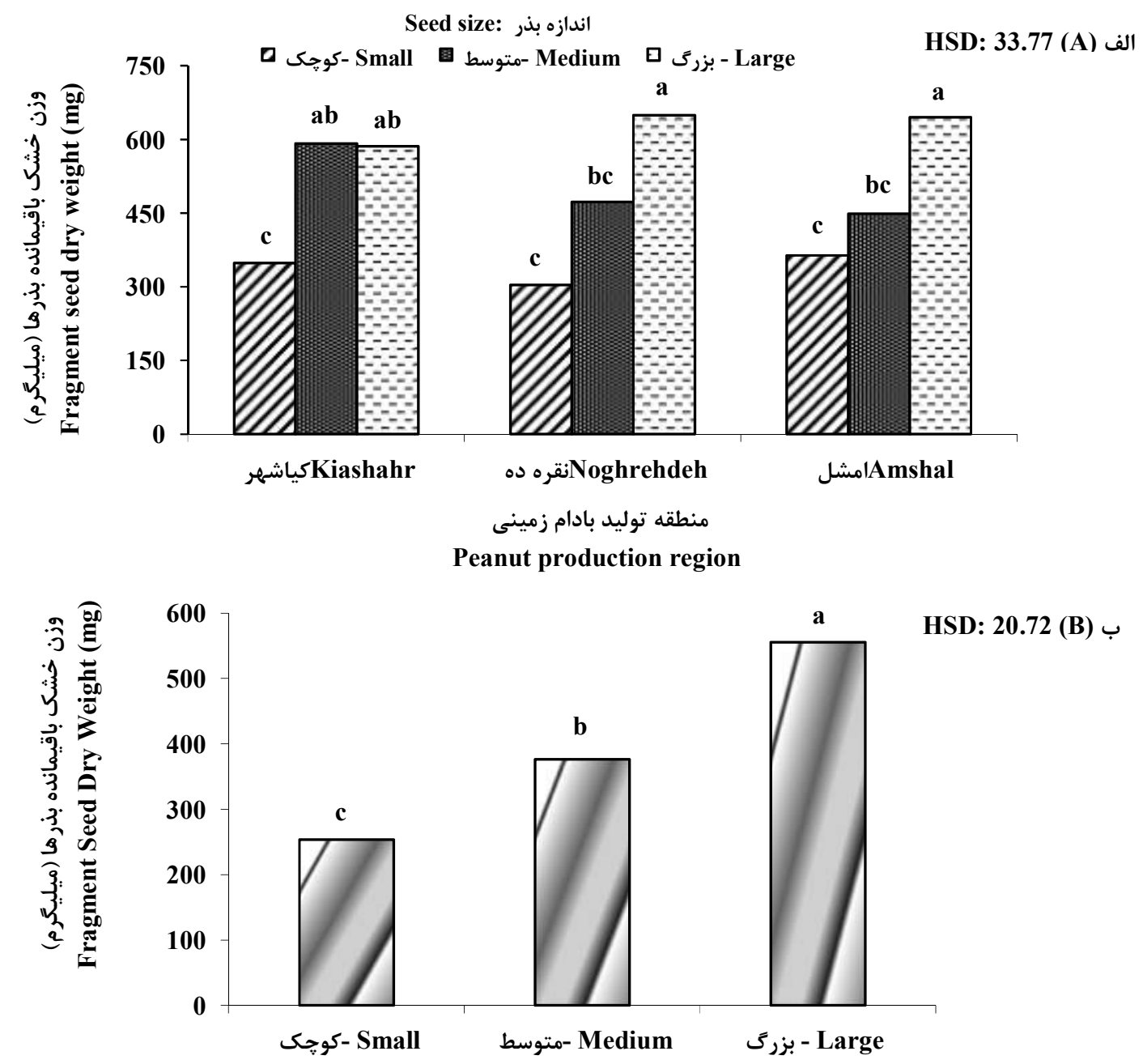

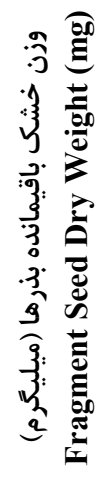

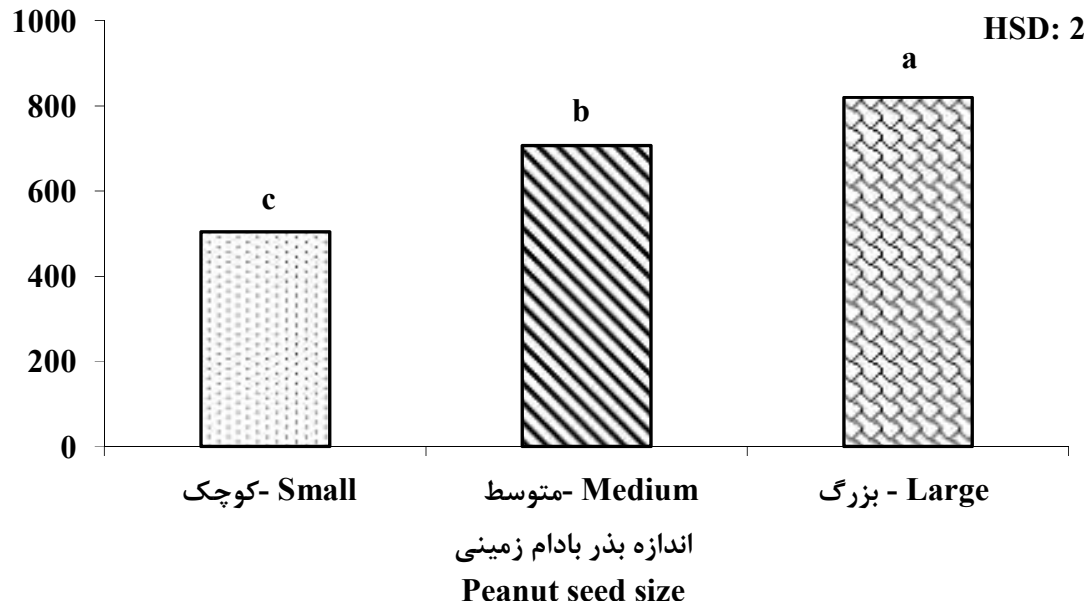

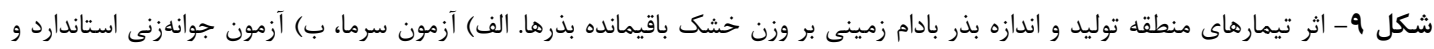

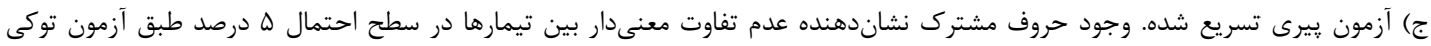

Figure 9. Effect of production region and seed size treatments on seed dry weight of seeds. Cold test (A), Standard germination test (B) and Accelerated aging test. Means followed by similar letters show no significant difference based on Tukey Test at $5 \%$ error probability. 

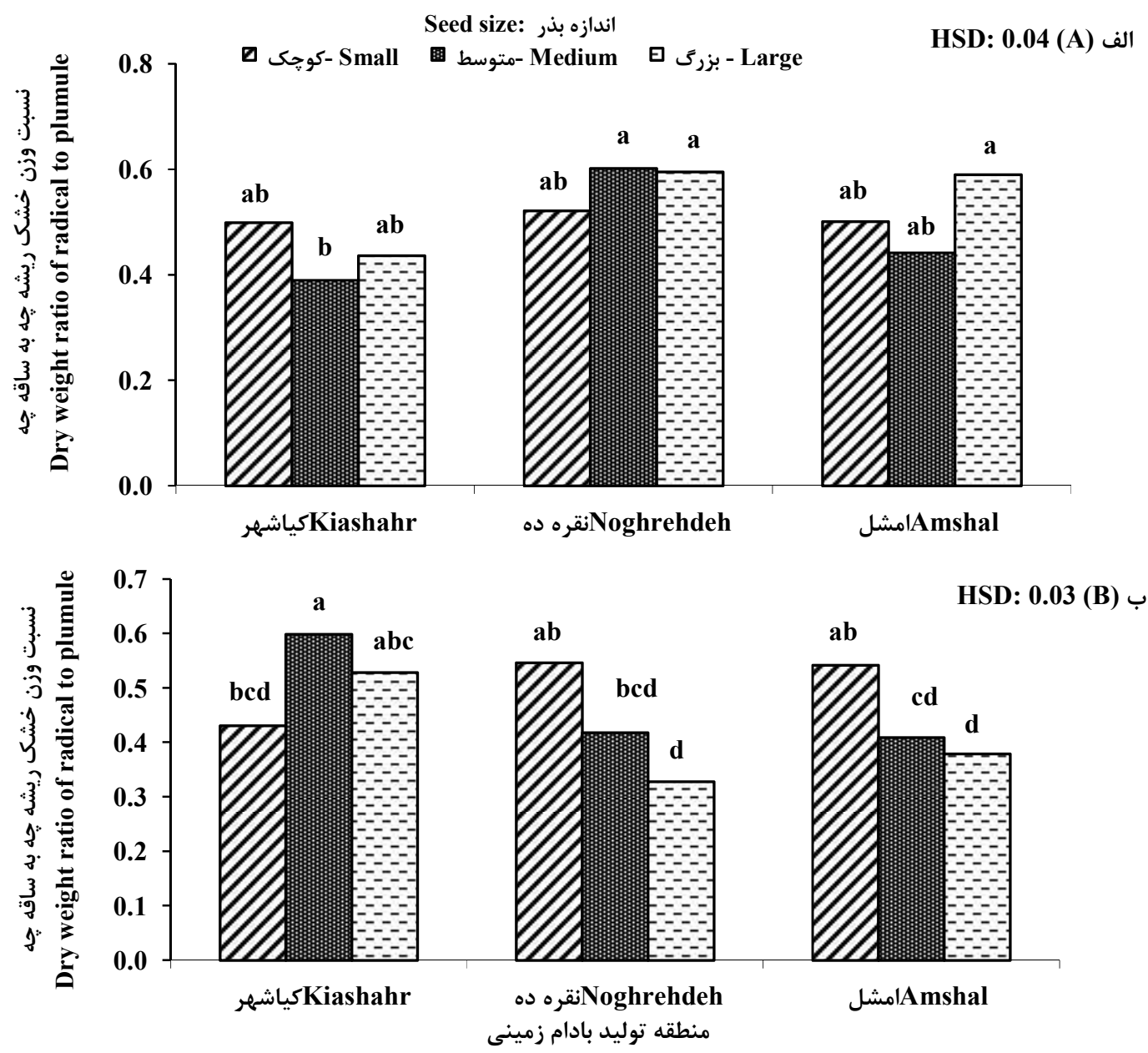

Peanut production region

شكل •(ا مقايسه ميانگين برهمكنش منطقه توليد و اندازه بذر بادام زمينى بر نسبت وزن خشك ريشه خه به ساقهجه. الف) آزمون سرما و ب)

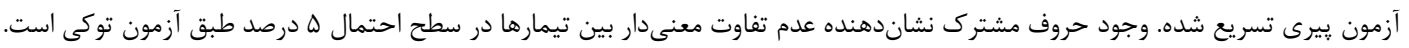
Figure 10. Effect of production region and seed size treatments on Dry Weight Ratio of Radical to Plumule. Cold test (A) and Accelerated aging test. Means followed by similar letters don't show any significant differences based on Tukey test at 5\% error probability.

برخوردار بودند. در حالى كه گياهجههاى حاصل از بذرهاى ريز، كوجكتر و ضعيفتر بودند كه از اين نظر ممكن است توانايى كمترى در رقابتهاى مزرعاد داى نيز

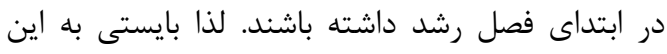
مسئله توجه ويزه نمود و بذرهايى كه جهت كاشت توليد مىشود حاصل از منطقه و مزرعهى مناسبترى جهت

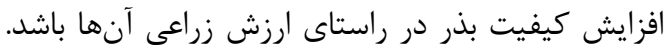
لازم به ذكر است كه كيفيت نامطلوب بذر و بذرهايى كه قوه ناميه يايين و يا كَياهجههاى ضعيفى توليد مى كنند

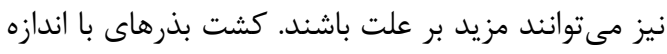

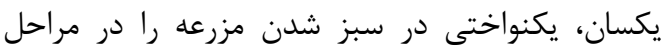

$$
\text { نتيجه }
$$

بلهور كلى نتايج حاصل از اين مطالعه نشان داد كه بيشترين سرعت جوانه و ضريب يكنواختى جوانهزنى در إنى

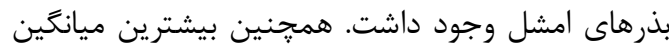
سرعت جوانهزنى متعلق به بذرهاى درشت توليد شده در منطقه امشل بود. بيشترين مقدار استفاده از ذخاير بذر دئر

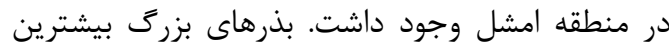

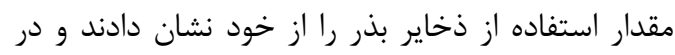

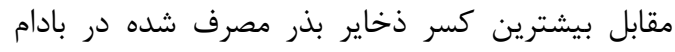

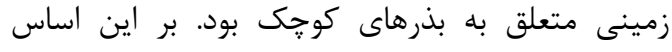

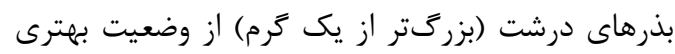




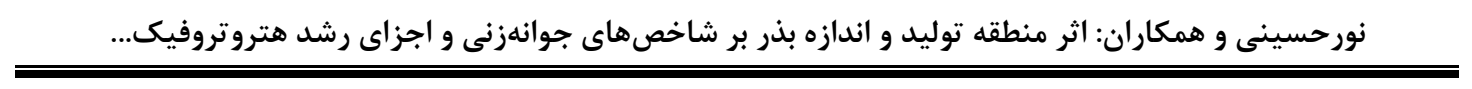

مصرف بذر در واحد سطح را كاهش مىدهد تخمين

بهترى را نيز از عملكرد اقتصادى گياه مىتواند به همراه داشته باشد.

$$
\begin{aligned}
& \text { بعدى دوره رشد گياه به وجود مى آورند؛ بنابراين انتخاب } \\
& \text { بذرهايى با خصوصيات كيفى مطلوبتر و اندازه مناسب و } \\
& \text { همجنين توليد در مزرعه مناسبتر، علاوه بر اينكه ميزان }
\end{aligned}
$$

منابع

Albuquerque, M.D.F., and de Carvalho, N.D. 2003. Effect of the type of environmental stress on the emergence of sunflower (Helianthus annuus L.), soybean (Glycine max (L.) Merril) and maize (Zea mays L.) seeds with different levels of vigor. Seed Science and Technology (Switzerland): 31(2), 465-479. https://doi.org/10.15258/sst.2003.31.2.23

Bell, M.J., Muchow, R.C., and Wilson, G.L. 1987. The effect of plant population on peanuts (Arachis hypogaea) in a monsoonal tropical environmental. Field Crops Research, 17(2): 91107. https://doi.org/10.1016/0378-4290(87)90085-2

Copeland, L.A., and McDonald, M.B. 1985. Principles of seed science and technology. 121-144.

El-Saidy, A.E.A., and El-Hai, K.M. 2011. Alleviation of peanut deterioration during storage using biotic and abiotic agents. Research Journal of Seed Science, 4(2): 64-81. https://doi.org/10.3923/rjss.2011.64.81

Fernandez, E.M., Rosolem, C.A., and Oliveria, D.M.T. 2000. Peanut seed tegument is effected by liming and drying method. Seed Science and Technology, 28(1): 185-192.

Fu, J.R., Huang, S.Z., Li, H.J., Come, D., and Corbineau, F. 2000. Seed vigour in relation to the synthesis and degradation of storage protein in peanut (Arachis hypogaea L.) seeds. Acta Scientiarum Naturalium Universitatis Sunyatseni, 39(4): 80-84.

Gholami, H., Babayan, M., Mosavinik, S.M., Ahmadian, A. 2010. Evaluation of heterotrophic growth of rice seedling and proline and solution sugars concentrations changes under seed deterioration levels. The 5th National Conference on New Ideas in Agriculture, Islamic Azad University, Isfahan Khorasgan Branch, 5p. [In Persian].

ISTA. 1993. International rules for seed testing. Supplement to Seed Science and Technology, 21: $1-288$.

ISTA. 1995. Handbook of vigour test methods. Edited by: Hampton, J.G., and TeKrony, D.M. 3rd edition. Published by: International Seed Testing Association (ISTA). Zurich, Switzerland, $117 \mathrm{p}$.

ISTA. 2009. Handbook on seedling evaluation. Edited by: Don, R. 3rd Edition. Published by: The International Seed Testing Association (ISTA). Bassersdorf, CH- Switzerland.

ISTA. 2011. International rules for seed testing, the germination test. Published by: International Seed Testing Association (ISTA), Bassersdorf, Switzerland, Chapter 5: 1-57.

Karimi, H. 2004. Crops. Chapter 5: Oilseed crop. Section 4: Peanut. University of Tehran Press, 242-246. [In Persian].

Knauft, D.A., Gorbet, D.W., and Martin, F.G. 1991. Variation in seed size uniformity among peanut genotypes. Crop Science, 31(5): 1324-1327. https://doi.org/10.2135/cropsci1991.0011183X003100050048x

Knauft, D.A., Gorbet, D.W., and Wood, H.C. 1990. The influence of seed size on agronomic performance of a small seeded spanish peanut line. In Proceedings. Soil and Crop Science Society of Florida, 49: 135-138.

Maiti, R., and Ebeling, P.W. 2002. The peanut (Arachis hypogaea) crop. Science Publishers. 376p. 
Mugnisjah, W.A., and Nakamura, S. 1986. Vigour soybean seed as influenced by sowing and harvest dates and seed size. Seed Science and Technology, 7: 87-94.

Nautiyal, P.C. 2009. Seed and seedling vigour traits in groundnut (Arachis hypogaea L.). Seed Science and Technology, 37: 721-735. https://doi.org/10.15258/sst.2009.37.3.19

Nautiyal, P.C., Joshi, Y.C., and Reddy, P.S. 1993. Methods to preserve seed viability in groundnut. Indian Farming, 43(8): 28-30.

Noorhosseini, S.A., Safarzadeh, M.N., and Sadeghi, S.M. 2016. Comparision the effect of hydropriming and osmopriming on germination and seedlings heterotrophic growth of peanut (Arachis hypogaea L.). Journal of Seed Ecophysiology. 1(2): 181-199. [In Persian with English Summary].

Perez, M.A., and Aryoello, J.A. 1995. Deterioration in peanut (Arachis hypogaea L. cv. Florman) seeds under natural and accelerated aging. Seed Science and Technology, 23: 439-445.

Razzaque, A.H.M., and Ali, S.N.A. 1991. Influence of cultivar sowing depth and seed size on the emergence of groundnut. Pakistan Journal of Scientific and Industrial Research, 36(8): 310-313.

Razzaque, A.H.M., Ali, S.N.A., and Hamid. M.A. 1994. Seedling emergence of groundnut as influenced by cultivar, sowing depth and seed size in a drying soil. Pakistan Journal Scientific and Industrial Research, 37(6-7): 255-257.

Sharma, P., Sardana, V., and Kandhola, S.S. 2013. Effect of sowing dates and harvesting dates on germination and seedling vigor of groundnut (Arachis hypogaea) cultivars. Research Journal of Seed Sciences, 6(1): 1-15. https://doi.org/10.3923/rjss.2013.1.15

Sibuga, K.P., and Nsenga, J.V. 2003. Effect of seed size on yield of two groundnut genotypes. Tropical Science, 43(1): 22-27. https://doi.org/10.1002/ts.83

Smartt, J. 1994. The groundnut crop. A scientific basis for improvement. Chapman and Hall Publishing, 756p. https://doi.org/10.1007/978-94-011-0733-4

Soltani, A. 2008. Effects of seed deterioration on seedling growth responses to environmental stress in wheat. Gorgan University of Agricultural Sciences and Natural Resources. Master's thesis. 66p. [In Persian].

Soltani, A., Galeshi, S., Zeinali, E., and Latifi, N. 2001. Genetic variation for and interrelationships among seed vigor traits in wheat from the Caspian Sea coasts of Iran. Seed Science and Technology, 29(3): 653-662.

Soltani, A., Galeshi, S., Zeinali. E., and Latifi, N. 2002. Germination, seed reserve utilization and seedling growth of chickpea as affected by salinity and seed size. Seed Science and Technology, 30: 51-60.

Soltani, A., Robertson, M.J., Torabi, B., Yousefi-Daz., M., and Sarparast, R. 2006. Modeling seedling emergence in chickpea as influenced by temperature and sowing depth. Agricultural and Forest Meteorology, 138(1-4): 156-167. https://doi.org/10.1016/j.agrformet.2006.04.004

Souhani, M.M. 2010. Seed technology. University of Guilan Press. Third Printing, 287p. [In Persian].

Tahmasebi, M., Galeshi, S., Soltani, A., and Sadeghipour, H. 2013. The effect of waterlogging stress on germination and heterotrophic growth components of wheat seedling in different temperatures. Electronic Journal of Crop Production, 6(3): 51-69. [In Persian with English Summary].

Trivedi, M.L., and Bhatt, P.H. 1994. The physiology of seed germination in groundnut (Arachis hypogea L.) cultivar GG-2 L effect of seed size. Journal of Agronomy and Crop Science, 172(4): 265-268. https://doi.org/10.1111/j.1439-037X.1994.tb00177.x 
Zeinali, E., and Soltani, A. 2001. Effect of water deficit stress on heterotrophic seedling growth of wheat. Journal of Agriculture and Natural Resources Sciences, 7: 113-122. [In Persian with English Summary].

Zode, N.G., Lall, S.B., and Patil, M.N. 1995. Studies on seed viability in peanut (Arachis hypogea L.) 1. Effect of soil calcium content on seed viability. Annuals of Plant Physiology, 9: 51-54. 


\title{
Effect of Production Region and Seed Size on Germination Indices and Heterotrophic Growth Components of Peanut Seedling (Arachis hypogaea)
}

\author{
Seyyed Ali Noorhosseini ${ }^{1, *}$, Mohammad Naghi Safarzadeh ${ }^{2}$, Seyyed Mustafa Sadeghi ${ }^{3}$ \\ ${ }^{1}$ Young Researchers and Elite Club, Rasht Branch, Islamic Azad University, Rasht, Iran \\ ${ }^{2}$ Associate Professor, Department of Agronomy, Rasht Branch, Islamic Azad University, Rasht, \\ Iran \\ ${ }^{3}$ Associate Professor, Department of Agronomy, Lahijan Branch, Islamic Azad University, Lahijan, \\ Iran \\ *Corresponding author, E-mail address: Noorhosseini@gilan.pnu.ac.ir
}

(Received: 05.04.2017 ; Accepted: 24.12.2017)

\begin{abstract}
To study the effect of production region and seed size on germination indices and heterotrophic growth components of peanut seedling, a study was performed in three peanut fields in Astaneh Ashrafieh and Agronomy Laboratory of Rasht Islamic Azad University from 2010 to 2012. This research was carried out using the standard germination, cold and accelerated aging tests. Tests were performed using factorial experiment with a completely randomized block design in 3 replications. The first factor was seed production region in 3 levels (Noghredeh, Amshal and Bandar-Kiyashahr) and the second factor was seed weight in 3 levels [large, medium and small]. The results indicated that the effect of production region on the germination speed $(p<0.01)$ and coefficient of uniformity of germination $(p<0.05)$ was significant so that the maximum means $(6.17$ and 18.11 day $^{-1}$, respectively) were achieved in seeds produced in Amshal. The effect of the interaction of the region and seed size on the mean germination speed was significant so that the maximum mean (282.22) was achieved in large seeds produced in Amshal. The effect of production region on the seed reserve use rate was significant in standard germination $(p<0.01)$ and cold tests $(\mathrm{p}<0.05)$. The effect of seed size on the seed reserve use rate and seed use reserve fraction were significant $(\mathrm{P}<0.01)$ in all the three germination tests. The maximum amount of seed reserve use rate was achieved in seeds produced in the Amshal region (in standard and cold tests with averages of 0.562 and 0.440 , respectively). In addition, the maximum amount of seed reserve use rate was achieved in large seeds (with averages of $0.541,0.470$ and $0.277 \mathrm{mg}$ per seed in standard, cold and aging tests, respectively). The maximum seed use reserve fraction was achieved in small seeds (with averages of 1.371, 1.310 and 1.664 in standard, cold and aging tests, respectively).
\end{abstract}

\section{Keywords: Seed size, Peanut, Germination, Heterotrophic growth, Production Region}

\section{Highlights:}

1- Peanut seed germination tests were performed based on seed production regions and seed sizes.

2- Three different vigour tests (standard, aging, cold) were used to identify higher quality seeds.

3- Germination indices indicated high quality in large seeds produced in different environmental conditions.

4- Large seeds had the maximum seed reserve use rate and minimum seed use reserve fraction at the germination stage of peanuts.

DOI: $10.29252 /$ yujs.4.2.57 